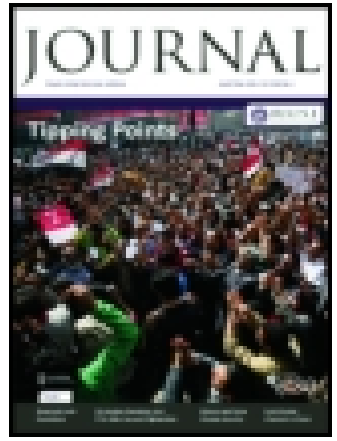

Royal United Services Institution. Journal

\title{
Examples of Military Operations in Madagascar by Foreign Powers and Native Campaigns, 1642-1881
}

\section{Captain S. Pasfield Oliver Late Royal Artillery F.R.G.S., \&c.}

To cite this article: Captain S. Pasfield Oliver Late Royal Artillery F.R.G.S., \&c. (1885)

Examples of Military Operations in Madagascar by Foreign Powers and Native Campaigns, 1642-1881, Royal United Services Institution. Journal, 29:132, 1003-1044, DOI:

10.1080/03071848509417997

To link to this article: http://dx.doi.org/10.1080/03071848509417997

曲 Published online: 11 Sep 2009.

Submit your article to this journal $\llbracket$

Џll Article views: 3

Q View related articles ¿ 


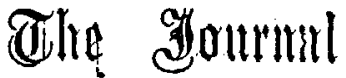

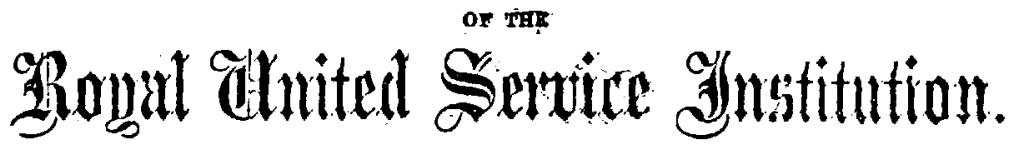

VoL. XXIX.

No. CXXXII.

Wednesday, July 8, 1885.

VICE-ADMiras W. GORE JONES, C.B., in the Chair. 15.2 .06

\section{EXAMPLES OF MILITARY OPERATIONS IN MADAGASCAR BY FOREIGN POIVERS AND NATIVE CAJPAIGNS, 1642 $-1881.1$}

\section{By Captain S. Pasfield Outrer, F.R.G.S., \&c., Iato Rojal Artillers.}

The Crrirusin: Ladies and gentlemen, a somewlat small attendance to-das does not prerent the lecture being one on one of the nost interesting topies that could be brought before an English audience at this moment. If there is one country in the whole world more than another in which England is interested, it is Madagascar. In the first place it is a rery wonderful strategieal position in the Eastern seas, and although we larre not cliosen to take possession of it or to make any use of it, it is absolutely necessnry that no cnemy of ours should erer get it. The first effect of such a hostile occupation mould be our disappearance from the Mauritius and from all our sugar plantations, and crerytbing that comes from that Colony. The people could not sustain themselres without Madagascar, they get all their food and the necessaries of life from therc; for that reason alone it is absolutely necessary to England. And not only the Mrauritius, but the whole of the islands of that Archipelago are dependent upon Madagascar. Then comes the great strategical position in caso of war. Our friends the French hare an eye to strategical positions. There is a great bay at the northern. part of tho island called Bembatokn Bay, where all the fleets in the rorld might anchor, and that is, I believe, the position they chiefly want. Thence ther could interrupt the whole of our Eastern commerce. The other day, before the French business occurred, I mas thinking of joining a company myself to work the trade of Mradagasear, and I have just a fer notes here that would be wortl reading. The island has a population of about $3,000,000$; it is 818 miles long by 300 miles broad, and, situated between $12^{\circ} 2^{\prime}$ and $25^{\circ} 40^{\prime}$ south latitude, is almost entirely within the tropics. It rises from both sides to an altitude of about 4.500 fect abore the sea lerel by a series of plains and platenus, some of which are from 30 to 40 miles wide. The geographical position and topographical configuration render itsooil capable of yielding the most raluuble tropical and sub-tropical products, such as coffec, cotton, indigo, sugar, rice; and it is not improbable but the tea-plant may find it home there also. They grow those products in a manner far superior to the Mauritius, for the Mauritius is getting somembat worn out. The silk produecd in Madagascar is of the finest quality, of which beautiful specimens were presented ta the Queen on tho occusion of the Enroy's risit. A band of forest owned by the

1 The Institution is indebted to Messrs. Macmillan for the use of the accompanying map prepared for their forthcoming work on Madagascar by Captain Olirer.-Er. tกT. Yriv 
Government, and from 10 to 40 miles wide, encircles the island. Besides other timber, it comprises ebony, rose, sandal, and other fancy woods. Thilo the plains of Imerina and some other portions of the island are thoroughly cnltirated, large tracts of raluable land remain untilled and uninlabited, as for example the region known as " no man's land." Extensive pasture lands also occur, orer which roam herds of cattle, in which there is an extensire trade, large numbers being exported to Mauritius, Réunion, and eren to Natal. There is in fact no country in the morld where cattle are so cheap as in Madagascar. Fat bullocks can be put on board ship at $40 s$, to $41 s$. per head, or at about $1 d$. per pound. Cattle are cheap in the island because there are no droughts, and because the grazing grounds are well watered and inexhaustible. Now these grazing grounds are but-one month's sail distant, and surely they may be rendered arailable for the supply of meat to the United Kingdom. The geographical position of the island from a commercial standpoint is most important. It is about midway betreen the Cape of Good Irope and Aden, and about seren days' sail from the Red Sea. Mrauritius is 500 miles distant. Its eouthern cud lies about 700 miles E.N.E. of Natal, and, its whole length, Biadagascar lies off that part of the const of Fast Africa in which most interest is felt. In fact it bears the eame relation to that great continent that Great Britain docs to Europs, and when brought, through Christinnity and commerce, into a higher state of cirilization, will exercise upon the African negro an important influense. The French call Madagascar, on account of its position, the future store: house of the Indian Occav. That position certainly will gire it an important and commanding influenee orer the African coast-trade from Zanzibar and Natal. With respect to sugar, a large trade is now carried on from Mauritius, as well as from that islard to Bowbay, the exports being in 1850-81 as follows:-Bombay, 39,470l.; Anstralia and New Żealand, 45,610l.; Cape ports, 6,29sl. against 15,613l.; to tho United Fingdoni. Sugar can be as profitably produced in Madagascar as in Mrauritius, and the growth of our Australian Colonies must naturally always secure an enlarging demand for the great staple, in the supply of which Jiadagascar may reasonably hope largely to share. The truth of the matter is, it is new soil, and the Mauritius is not, and its capabilitics are rery great. Now I hare not come here to gire a lecture mrself, so I will come to a conclusion, and I hare great pleasure in introducing the lecturer of the day, Captain Olirer, who knows a great deal about the country, and I lave no doubt will give us an interesting description of ererything that he proposes to bring before you.

Captain Orirer: I must ask the indulgence of the audience this afternoon, if they will allow me to refer to the absence, through death, alas! of my much-ralued friend Admiral Joln Crawford Wilson, R.N., whose sudden death has taken all his friends by surprise. He woudd hare been here this afternoon had his duties permitted him, and in fact, possibly mould hare taken the chair. His interest in the IIalamasy ${ }^{1}$ was great, and his position as a well.known member of this Institution, apart from his well-known carecr in the Royal Nary, is sufficient to draw from us all a tribute of sincere heartfelt grief at the loss which this Institution has sustained by his death at the very period when his country looked upon him to fulfil the expectation formed from his former strict and stainless life of honour. Doubtless the shock sustained by his roluntary entrance into the engine-room of H.MI.S. "Thunderer" Then the explosion took place gare an additional strain on his constitution which has probably contributed towards his untimely death. I must also lament the loss of another friend of Madagascar, Lieutenant H. Horace Hajes, First Lieutenant of tho "Bacchante," who gare me a great deal of information about Madagascar, and whose royage down the east coast of Madagascar has erentuated in his death. He died on the 13th June."

1 Admiral Wilson commanded HI.II.S. "Gorgon" in 1862-63, and conveyed the British 3rission (of which Captain Oliver was $n$ member) to and from Tamature. Ifo also risited the mest const, and contributed a paper on the Sakalara tribes to the Rogal Gcographical Socicty's Proceedings. (Sce "Notes on the West Const of MLałagascar," R.G.S. Journal, rol. ixxri, p. 241.)

. 2 Lieutenant IIenry Horace Iages, R.N., died on board the P. and $O$. steamer. 


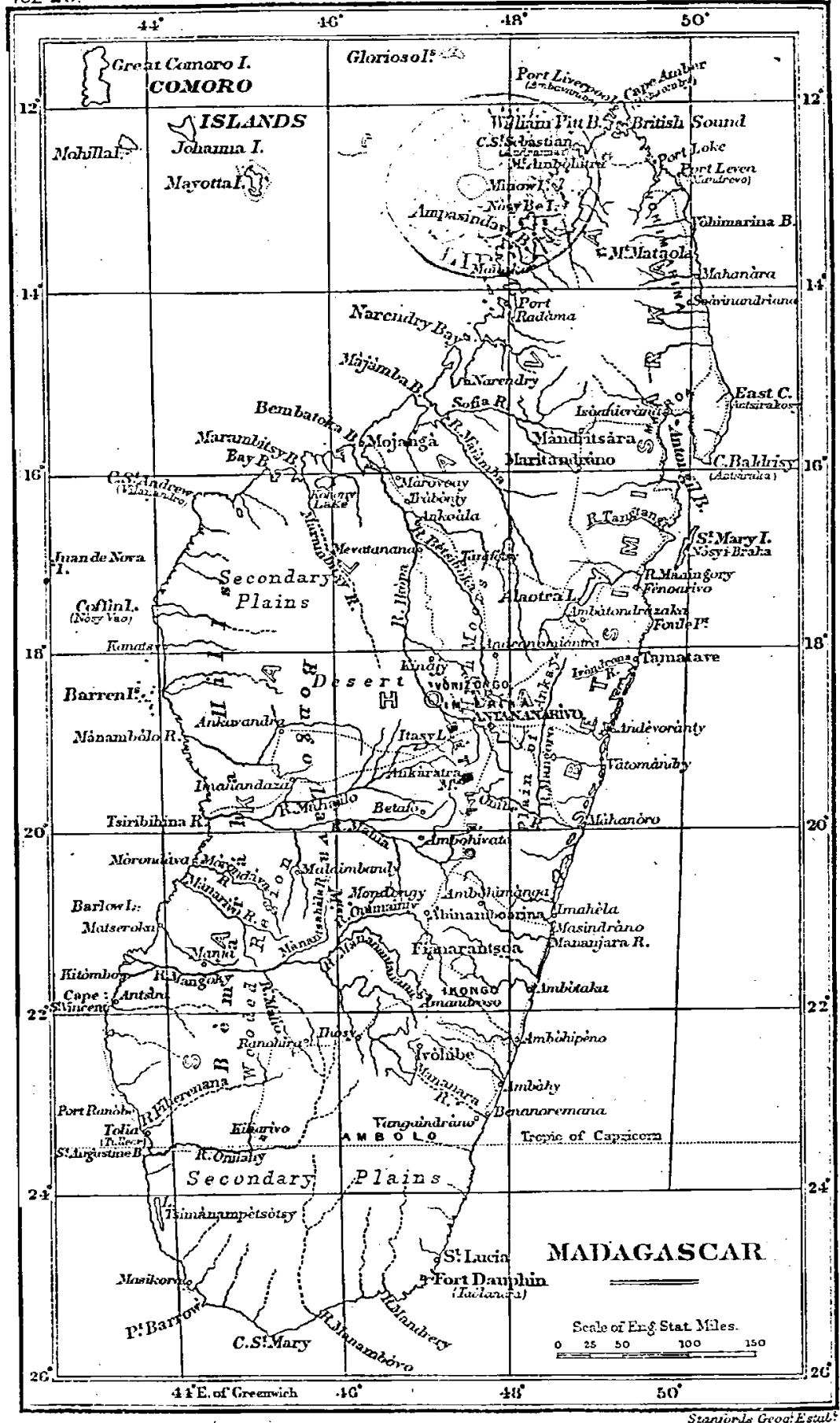




\section{I.-Elardest Frexch Operitions during the Sefexteexth Centurt.}

Tine subject on which I treat this afternoon does not carry us back further than the seventeenth century, when the attention of European uations was turned gencrally to colonial expansion and the acquisition of nnoccupied territories.

Ia 'Société de l'Orient.-Armand Duplessis, Cardinal Richelieu, during tho latter days of Lonis XIII, established the Société de l'Orient, fire months before his own death in December, 1642, for the express purpose of founding a permanent Colony in Madagascar, or Saint Laurent, as the island was then named. The letters patent granting a concession of the island of Madagascar and adjacent islets to the company were signed in the following year, 1643, by Louis XIV.

First French Settlements.-Pronis, a Huguenot, and Fonquembourg first established the small French Colony at. St. Lucia; but the unhealthiness of the locality caused the speedy removal of the settlement to a peninsula at the sonth-enst corner of the island where they built Fort Dauphin.

From the very outset misfortune attended the French efforts at colonization in the island. "Not only was the mortality excessive, but religious differences caused the Catholic truops and colonists to revolt against the Huguenot chief. 1 . Pronis was deposed and confined by the mutineers until rescued by a reinforcement from Europe. On the occurrence of a second outbreak of insubordination, Pronis managed to subdue the rising, and deported the ringleaders to the Grande Mascareigne (now Rénnion), but he was superseded by the Sieur de Flacourt, who was sent from $L_{a}$ Rochelle to take command of the Colony in 1643 .

De Flacourt's Expedition.-De Flacourt aimed at reducing the whole of Madagascar to a state of subjection, and soon after his arrival took adrantage of some slight provocation to send an expedition of eighty men under Sicur Angeleaume to destroy the torn of Fansherc: On this occasion the Chief Dian Ramach was slain, and the villages and property throughout the district pillaged and burnf. The Roandrians, or petty kings of the tribes as far as St. Augustine's Bay, were all subdued or overawed, and submitted to pay tribute to the French at Fort Dauphin. Nerertheless the settlement was neglected by the home anthorities; during the seren jears of De Flacourt's administration no supplies were sent from France; and in 1653, the charter of the Society having expired, De Flacourt returned to Europe, leaving Pronis again in charge of the establishment at Fort Dauplin.

"Tenctia," off Suez, on 13th June, 1855, inralided from II.M.S. "Bacchante." When belonging to II,MIS. "Tourmaline" he was especially mentioned by Captain R. Boyle, R.N. (now of II.JI.S. "Iron Duke"), for his bout rofages on the cast coast of Iradagascar during tho French blockade in 1884.

- Pronis is accused of selling publicly to Fan der Mester, Gorernor of Mauritius, a number of natives engaged in the service of the French Colony, including sixteen women, relations of IIalagass chiefs. $\therefore$ These unfortunate slarea, on arriring at Mauritius, fled to the woods and mountains, where they became Maroons. 
In 1655, Fort Dauphin was burnt, and the next Governor sent out by the reconstituted Society was M. Chamargon, who arrired at the settlement in 1660. The fort was rebuilt and tho houses reconstructed by 1663.

Victorious Enterprise of La Case.-Ln Case, the lieutenant of Chnmargou, was despatched by the Gorernor to reconnoitre the district of MIatitana, a mission which he carried out with intelligence. The real name of the young Officer was $L$ Vacher, a nativo of Rochelle; he had taken the name of La Case as a nom de guerre on joining the expeditionary forces of the Sociéte dle l'Orient as a soldier of fortune. On his arrival at Fort Dauphin he fonnd that the relations between the French and the natives of the island were of the most unfriendly description, and he recognized the necessity of re-establishing the repatation of the French Colonists among the neighbouring tribes. After several victorious engagements $\mathrm{L}_{\mathrm{a}}$ Case gained by his tact and valonr such an inflaence over the southern tribes that the Malagasy named him Dian Pousse, the title of a great chief reputed to hare conquered the whole island, and whose memory and posthumous name were held in reneration by the warlike people. 'The sovereign of the fertilo province, Ambolo, Dian Rassitate, offered his daughter, Andrian Nong, in marriage to La Case, who with fire of his companions had left the French Colony clisgusted by the condact of Chamargou. On the death of Dian Rassitate, Ia Cass was elected chief of his wife's tribe, and speedily became master of a large portion of the island.

Meantime the establishment of Fort Dauphin was reduced to the greatest straits through sickness and famine, until their necessities were reliered by supplies of rice and beef which were furnished by La Case.

Chamargou, haring reccired reinforcements from France, waged another cruel war against the tribes of Carcanoss, and the murder of a French missionary by Dian Manangue, Chief of Mandrerey, led to sangninary reprisals. A detachment of forty firenchinen was cut off and massacred by a chief, La Vatangae, and Chamargou himself led all the arailable men ho had against Dian Manangue. Dian Manangue assembled a force of, it is said, 6,000 men to dispute the passage of the river Mandrerey against Chamargou, and the French would doubtless hare been destroyed, had not La Case, nccompanied by 3,000 Malagasy of Ambolo, attacked the tribesmen of Dian Manangue, and covered the French retreat to Fort Dauphin. Even then the garrison would have been starred had not La Case convoyed 5,000 bullocks into the fort which was blockaded by Dian MIanangue.

La Compagnie Orientale.-Under the auspices of Colbert a new company was formed, on the model of the English East India Company, in 166t, to which all the rights of the Société de l'Orient over the island of Saint Laurent, were transferred. This company was named $L a$ Comprignie Orientale, and tho island of Mrdagascar receired the name of Ile Dauphine. This last name, however, was not prescrved, for we find that in tho following sear, 1665, this island was re-ramed La France Orientale, and Ji. do Reunefort 
assumed the reins of its government. The first act of the new com. pany was to send a sword of honour to ha Case, togather with his commission as Major; in return for which that Officer pledged himself that if a force of 200 Frenchmen mere placed under him he would conquer tho whole island, and estabiish the permanent authority of the King of France throughout Madagascar.

In 1667, the Comte de Mlondevergue arrived with a fleet at Fort Dauphin, and; by the assistance of La Case, an arrangement was arrived at with the powerful chief, Dian Manangue; who swore fealty to the French Gorernor-General, and undertook to keep the garrison supplied with prorisions. The grand Compagnie Orieatale, however, failed through the maladministration of the funds, and Madagascar became a Crown Colony under the Viceroy; Admiral de la Haye.

Adniral de la IIaye.-Adniral de la Haye impeached the former Governor de Monderergue (who died of chagrin, a prisoner at Saumur), and instituted at once an aggressive policy. Netermined to overawe the neighbouring chiefs who would not acknowledge his authority, he ordered Chamargon and Major La Case to summon Andrian Ramousay to surrender all the arms in bis possession. The summons not being complied with, Chamargou and La Case attacked the chief's town with 700 French and $600^{\circ}$ native allies. Andrian Ramousay, howerer, made a stout resistauce, and repulsed the French attack. It was beliered that Chamargou behared treacherously on this occasion, and contrired the failure of the assault.

Admiral de la Haye finding that his foree was insufficient to cope with the natires, left his command and sailed for Surat. His departare was shortly followed by the death of La Case, whose name and repatation for valour alone kept tho islanders in subjection to the French. Their condnet had become intolerable to the MIalagasy tribes, who only atraited a suitable opportunity to rid themselres of the foreigners. On the death of Chamargon, his son-in-law, Le Bretesche, succeeded as Governor; bat finding his anthority disregarded by those beneath him, he also took advantage of a ship put. ting in to Fort Dauphin to embark himself; family, and a few followers. The ship had no sooner set sail than a signal of distreiss was observed on shore. The Captain sent off his boats, which succeeded in rescuing a few individuals remaining after a dreadful massacre effected by Dian Ramonsay and the other chiefs. This tragic erent took place, it is said, at midnight on Christmas Ere, when the French wero attending service in the chapel withont the gates of the fort, December 25, 167\%. No. French establishment was again posted on the shores of Mladagascar for upwards of a century.

Rentarles on the French Operations during the Seventeenth Century.From the "History of Madagascar,"- written by ML. de Flacourt, we are euabled to form an accurate estimate of the state of the natires in the southern portion of the island, with whom the Frenchmen of the seventeenth century had to deal. We find that the tribes of Anosy, and the Ambolo Valles; the Machicora and the Mahafali, the 'Tsienim- 
balala, and Antaisaka; preserve to this day all the characteristics of their ancestors, and are not in the least changed in their manners and customs from what they were when they were first intruded upon by foreigners. The tribes of the sonth end of the island of Madagascar, outside the tropic of Capricorn, belong to that branch of the Malagasy which includes the people now known as the Sàkalàra (or long tongites).

II. de Flacourt describes these people, their social condition, and surroundings minutely, and they perfectly agree with the modern accounts of the southern and western Sakalara given by the Jesuit missionaries who hare resided at St. Angustine's Bay and Baly Bay; as well as with the descriptions accurately recorded by the Norwegian Protestant missionaries at Tolear.

From these sources it is erident that the Sàkalàra and all the. mest tribes are incapable of sustained military combination or civil organization. They lare remained unimproved for the last two centuries; if, indeed, they are not more degraded from their ancient simplicity by the introduction of gunpowder and muskets, ram and arrak, and the means of purchasing these commodities by the betrayal into slarery of their comrades and relations. Nerertheless the suceessful operations of men liko La Cose show that under good leadership and organization their tribesmen are not incapable of doing good service at least against their own equals, and doubtless if properly disciplined could be drilled and made as efficient as the JIadras Sepoys. Unfortunately whatever was undertaken by the French during the seventeenth: century was carricd out on too small a scale and by the wrong class of men. Their leaders were not-supported from home, and the knowledge of orercoming the local malarious fever was wanting. Coercion instead of conciliation was the policy of all European expeditions in those days, and the result was an undying hatred of the foreigner by the inlabitants, by nature more timid and docile than ferocious and untameable.

The West Coast Tribes.-The rarious Sàkalìra tribes are perfectly independent and jealous of one another, seldom remaining long on a friendly footing with their neighbours. They are frequently at war, and many are the causce belli, such as cattle-lifting, robbery, quarrels about hereditary fiefs, insulting personal remarks between the chicfs, disagreements with regard to boundaries and pretensions to supremacy, \&c. But although the tribes make war against each other so often their battles aro not very serious, nor the casualties numerous. If any are killed it is immediately known on both sides, and all becomo sorrow-stricken. The weeping women stand up to negotiate peace; and the war censes until a new quarrel again offers an opportunity for recommencing hostilities, and they have not very long to wait. Although they are so violent in war, the number of killed, under the circumstances, is very small. They fight in rery, extended order, and every warrior is particularly carefal to remain under corer, so they blaze away, expending plenty of ammunition with the minimun of effect. When danger is near they take good care to escape in time; and the sight of a comrade: shot or captured will cause a 
gencral panic. Erery ore fights ou his own hook, and has not tho slightçst confidence in his own side assisting him. Should a man fall, he is left to his fate, and no Sakalàra would dream of an nittempt to rescice or defend his commde. Ono chicf reason for this lack of courage and cunfidence is that they are often compelled to fight against. their own relations should they be. among the enemies of their king. Whien war is proclaimed all the people are obliged to follow. their king whether they like it or not; and if any one dared to make an excase. on the ground of not wishing to fight against friends and relations, he would expose himself to crael treatment. If a warrior thinks it more advantageons to him to join with the chief's enemies, ho will freqnently becowe a deserter. The Vezo (coast tribes near St. Augustine's Bay) are especially given to this sort of desertior.

The most sccure retreat for deserters is the Fiherengn kingdom, which is the lirgest and most powerful of all the independent bingdoms, and offers the most sceure protection for runaways.

The many petty princes in this kingdom, sons or relations of the present King Lahimorisa, gather together as many men as possible for their orn individual ends (for they are alrars figliting with each other); and in consequence, that old weak chief hes no power to carrs out his laws. All deserters from other kingdoms are accepted and welcomed in this Alsatia by these petty chiefs, who liko to have a large number of followers ready to fight, rob, or plunder, and do every kind of evil deed. On this acconit the Filierenga province is the most insecuro as to life and pioperty throughout Madagascar:

The Sàkalira consider it possible to keep on gooll terms with all except the Hova (or Ambaniandro), against whom they have sworn an eternal cnmity. Eren when tighting with other tribes they do not regard them as their enemies. The only tribe they regard with real hatred is the Hovi, as they. believe that the Hora is the only tribe which interids to subdue the Salkaliva and seize their country. Rather than become subject to the Hova, and give up their independence, they would exterminate themselres by warring against cach other.'

Sàlialita Warjare.-Tho Ampisiliely, or soothsayers, propless when war may be expected to be declared by any neighbouring king. The Ampisiliely, on being asked whether there shall be war or not, takes his dirining ipparatus, generally a small board divided into squares; on which some sinall stones are placed-tho wisclom stones. His divination's are oracular; then he sass; perhaps; the enemy way begin to make rear upon the kingdoin in the beginuing of the next month; if 'not then it may be about the time of the riext now moon; and so on, till even: half-a-year has passed away, but the enemy makes no appearance at all:

When war, Lowerer, is actually declared, whether a war of aggression'or defence, the chicftain appeals to his followers, aud the men gather at the appointed rendeztous; generally the: king's residence. 
When assembled the first thing thought of is to secure a proper charm or talisman. The sorcerer, Onsitra, obtains a black bull calf and a cock. These animals are buried alive, and when covered with earth a mark is put on the spot. Then the adrancing encmy sees the potent sign he is supposed to retiro and war is averted. But sometimes the enemy will make a flank march to aroid the hidden danger; and again the Onsitra is summoned to provide medicine to instil valour into the tribesmen. This is generally provided in the shape of an ox-horn full of grease, with which the warriors anoint their bodies, thereby rendering them presumably invulnerable. The warriors then start shouting and singing their war song, until the hostile forces aro near enough to shout defiance at one another, when a halt is called. After an interchange of compliments, the firing begins, and should any one fall his fellows take to flight. The enemy run up to the fallen man, spear him, and plunder him, and the battle is over for the das. The Salkalàra only approach each other. near enough to use their spears when very excited, and this game is repeated for weeks and eren months. The vanquished receive no mercy from the rictors, who carry away the women and children, cattle, and any other property they can lay hold of. Tars of this kind are constant, and are much enjoyed by the Sàkalàra, for there is littlo real bloodshed.

The Sàkalàra tribes are now in much the same condition as they were in the days of Flacourt. ' From their frequent intercourse with Earopeans in the Mozambique they obtained a knowledge of the use of firearms, and cheap muskets, gunpowder, and rum have alwajs been the chief articles of commerce on the west coast. The posses. sion of firearins enabled them to exercise military supremacy throughout the westem and warmer portions of the island from north to south, and the highland tribes of the interior were subjected to blackmail. The province of Imano, indeed, paid tribate to the Sakkalàva of Menabé until the Hovas, obtaining arms and ammunition, were able to turn the tables on their more swarthy neighbours.

1774. After the abandonment of Fort Dauphin and the destruction of the garrison, the intercourse between Madagascar and Europeans was for a long time most casual, and the southern provinces of the island were left to themselves. But at about this period the pirates who infested the Indian Ocean made settlements at St. Mary and Antongil Bay, from whence they sent out marauding expeditions, unt 1722, when the piratical haunts were destroyed by the Portugraese. French adrenturers, of similar calibre to La Case, successfally established themselves in the neighbourhood of Antongil Bay, notably one Bigorne, who was recognized as Commissioner of Trade by the Gorernment of Mauritius until the arrival of Benyowshy. Benyowsky was a Polish adventurer who escaped from Siberia, and was entrusted by the French Government with the establishment of a military colony at the head of Antongil Bay, where he arrired in 1744 . The natives were at first ready to be friend!r, as they had been with Bigorne, but Benyowsky, whose fol. lowers were as anprincipled as himself, soon involved the whole 
country in war ; and instead of instituting a self-supporting establishment, capable of exporting provisions to Mauritius und Réunion, his expedition required provisions from without, and consumed the depôt of supplies intended for tho French island colonies, which are entirely dependent on Madagascar for sustenance."

Benyowsk, with 300 Europenns and 3,500 native allies, mado an expedition against the northern Saikalàra. As ho advanced he was joined by numerous tribes, so that when he approached the Sàkalàva camp his forces amounted to 16,313-a swarm of locusts attracted by the prospects of plunder. An engagement took place, in which eighty Sàkalàva were killed and fifty wounded, after which tho enemy sued for peace. His conduct not being approred by the French, he resigned his command and nent to Europe, where he in vain sought emplojment in Mndagascar by the French, English, and other European Governments. At length, obtaining money and goods in America, he returned, and attempted to found an independent government of his own, and, having appropriated the stores of the French Government, a frigate was despatched from the Isle of France, from which a detachment was landed at Angoncy, under Captain Larcher, to capture him. The Pole offered resistance, and mas killed by the first rolley from the French marines, who took possession of the fortified post the adrenturer had occupied.

1810. Origin and Development of the Hova Military Supremacy.Hitherto the coast tribes only had been known to Enropeans, and from the abore notice of the Sakalày, who represent them, it is evident that thes have been ever looked upon by civilized nations as incapable of forming a strong government of their own.

Whilst Bigorne and Benyowsky were causing internal dissensions and fruitless attempts at civilization on the coast, in the interior highlands of Madagascar a tribe of superior intelligence was beginning to comprehend and make use of combination as a means of adrancement and power. The origin and previous history of the Hovas is too obscure and romoto to enter upon here. It is sufficient to say, that when MIr. Farquhar came to Mlanritius, he found amongst the records accounts of the growing supremacy of the Horas in the elevated plateaux of Imerina.

Andrianimpoinimerina had saccessfully combined the scattered clans of a certain district, sometimes called Ankova, and established a small kingdom, which he was gradually enlarging by the successful annexation of the adjoining provinces. Having established communication with the Arab slare-traders of the north-west coast at Mojangà, along the line of the Iliopa River, the Hova chief had obtained muskets and ammunition. His people also possessed a plentiful supply of natural iron, and the knowledge of smelting and manufacturing tools and weapons. They were large raisers of cattle, possessed extensive rice-fields and pasturages, and were perfectly independent of exterior assistance. They were hard 5 , intelligent; and brave, and although small, agile and wiry: Each village was a fortification, and when Mr. Farquhar first discorered their capacity and aptitude for improvement, the founder of the combined nation had lately died and been 
sncceeded by a young ambitions monarch, with a French deserter from Réunion as a companion, who had imbicd him with Napoleonic ideas. Radama, born in 1792, was only eighteen years of age rhen lo became king, in 1810, just after his father had consolidated his kingdom and sabjugated tho Vakinankaratra, the most formidable tribe of spearmen and warriors thronghout the island.

1820. The Campaigns of Ralama I.-Radama I followed in the footsteps of his father, and deroted lis attention to the subjugation of the entire island of Madagascar. Of his early campaigns we hare no record; but in 1816 Captain La Sage, aide-de-camp to Governor Farquhar of Mauritius, took up somo British soldiers to Antananarivo, and left Sergeant Brady and another non-commissioned officer to drill Radama's troops in European fashion. By the treats made in 1817, England agreed to pay Radama a jearly subsidy, including 100 English 'Tower muskets with accoutrements, 100 barrels of powder, 10,000 flints, 400 suits of uniform, \&c. ; so that by 1820 he felt himself powerful enough to commence a war on the Sàkalàra of Mienabs, to whose chieftain the Hova district of Imamo had long been tributary.

A considerable force was therefore sent to the west ander 1 . Robin; a lirench deserter: but tho Sàkalàva suceeded in repelling the invasion of their territory, and the French leader and the Hora troops returned to Antananarivo in disgrace. Mleantime Sergeant Brady contiuued his unwearied exertions with the troops; and by dint of hard drill and severe discipline at last organized a body of picked soldiers, which formed the nuclens of a larger arm5, the lbritish words of command being used.

1821-22. Subjugation of the Salialùra.-In tho antumn of 1821 Radama was so far encouraged by the improved discipline of his troops, ns to turn his thoughts to the further prosecution of the wa. with the Sàkalara. For this purpose a kabary was held at Andolhalo, when from 40,000 to 50,000 persons were present. It was then resolved to rencw hostilities, and that every man capable of bearing arms should go to war, or pay a forfeit of 10 dollars. Preparations for war were accordingly mado during tho rainy season, and early in the ensuing spring the peoplo were ready to commence the expedition. Including a thousand disciplined troops, with slaves, bedrers, and attendants, the whole aggregate amounted to 70,000 or 80,000 men.

On the 23rd June, 1822, abont 500 Maroserana, heads of districts, assembled in the court-yard of the palace; bearing their shields and spears, assuring their monarch of their fidelity in the approaching war, and betting wagers from 5 dollars to 1,000 -tho coward to pay the brave. The king stood at the door of his palace, holding his spear and shield, exciting the ardour of his people by his actions and addresses, prompting them to bet high, promising to confer his greatest honours on the brare and to reward them with 9 dollars for overy head of the enemy; at the same time representing the. Salkalàva country as abounding in cattle, where abundance of booty might bo obtained:

At daybreak on the 24th Jnne, cannon were fired as the signal of 
departure: The king, acting as priest as well as Commander-inChief, sacrificed a cock and a heifer, and offered a prayer at the tomb of Andriambelomasina, his renowned grandfather. Mounted on a filaizzan, carried on men's shoulders and accompanied by Mr. Hastie, the British Agent, surrounded by his body guard, the king then took lis departure from the capital. The national idols were taken with the headquarters of the army, whilst each clan or tribal division took its own idol, and erery soldier possessed a private charm or odly. The astrologers, mpanandro, ${ }^{1}$ and diviners, also formed a species of intelligence department, directing the dass of marching, the direction, the watering places and sites for encampments, inclicating the fords, strateg $y$, and tactics of the campaign. 'The birds crossing the path or flying over the heads of the troops mere also carefully observed, as anguring well or ill to the expedition.

Of this rast multitude, the men kept their own respeative clans, and each territorial regiment had its own leader, each individual soldier furnishing himself with his own weapons, whether gun or spear: and shield. Imerina was almost deserted by the departure of the troops; few able-bodied men being left, but only the women and children, the aged and infirm. Raholatra, brother to Ramitraha, chief of the Săkalìra, acted as guide: having quarrelled with his brother he thus turned traitor. But Radama placed no trust whatever in him, and had him watched closely by 100 men.

. The army advanced in short stages to the west and various routes assigned to the different divisions, which were ordered to assemble at a given rendezvous on a certain date. On the 8th July, the day when the army was expected to cross the Sàkalàva frontier and encounter the enemy, all the females at the capital arose at day-light and assembled in bands facing the west, sang war songs, and brandished sticks liko spears in tho direction of the enemy. This expedition lasted until October. Its principal object was ostensibly. to search for Ramitraha and his followers, in reality to seize whaterer booty could be secured. In these pursuits the conduct of the Hovas is said to have resembled rather the rarening of wolves than the deliberate attack of warriors. If they could seize cattle or surprise a few defenceless people, they rushed upon them with fury; but in any moment of danger no one cared for his neighbour, only caring for himself.

Fever and want of provisions proved dreadfully destructive to the troops in this expedition. It was calculated that not fewer than 25,000 or 30,060 perished in the campaign, and most of these from hunger. The stock of provisions carried from Imerina was consumed, and no supplies could bo obtained. Eren Radama himself and the British Agent had a mere handful of rice and a few birds,

1 "- quod apud Germanos ea consuctudo esset, ut matrez familin'corum Bortibus et raticinationibus declararent, utrum prolium committi ex usu esset, nec ne: eas'ita dicere, 'Non esse fas Germanos superare si anti noram lunam prolio contendissent." -(Casar, " De Bello Gallico," Lib. I, Cap. L.)

"Coëunt... cum aut incolatur luna, ant impletur; nam agendis rebus hoc auepicatissimum initium credunt."-(Tacitus, Germ. 11.)i 
which the latter shot, daring the space of eight days. The people died on the road, unable to sustain the complicated evils of malaria and want of regular supplies. For months afterwards not a day passed without the firing of musketry in some part of the capital, indicating the arriral of the corpses of those fallen in the war. The bones only were thas brought, the flesh being scraped off on the spot where the decensed fell. The Sàkalàra were hunted through the woods, and took refuge in cares and inaccessible retreats.

Rasalima, the daughter of the Sàkalàva Chief Ramitraha, who subsequently married Radama, remarked to some Officers who had accompanied the latter in his expedition, "We saw you, during your whole march, and observed all your movements in search of us. We were near you in the woods, and concealing ourselves in caverns; and on one ocension you actually walked orer our hends, without ever imagining we were so near." Yet there were several thousand men with Radama and as many with Ramitraha.

The Hora took rast numbers of slaves and cattle, and captured Mananarivo, the capital of Ramitraha, only some 15 miles from the Mozambique Channel, where the household gods of the Sàkaliva Chief were taken possession of, as well as two pieces of ordnance, which were buried in the bed of the River Mania, and afterwards brought up to Antananariro by Ramauetaka. But the Sàkalàva remained unconquered.

The king made a halt on his return a few miles rest of Antanamarivo, where he and his followers, after performing a religious ablution, made a triumplant entry, proceeding in pomp to the holy stone at Andohalo. A general labary was held, at which honours were conferred on the Officers who had distinguished themselves during the campaign.

1823. A Regular Army constituted.-Tho losses sustained by the Hora army during the campaign against the Sàkalàva were keenly felt by the inhabitants of Ankova, who showed a decided disinclination to again proceed on such another expedition. In consequence, at a great kitbary, Radama annonnced that he wished no more to take the people in a body to the war, that the last expedition had been a lesson on that subject, and that henceforth soldiers only should go ont to subduc the enemy, to quell disturbances, to subject the island to his gorernment, to protect the innocent, and to secure peace and tranquillity to the kingdom. " And for these reasons," said the king, "it is necessary that the regnlar army should be augmented. $A s$ to the numbers requisite, and the quota of nen each district should furnish, that I leare you to delibernte upon; at the same time, those who are not selected for soldicrs, but who remain at home, mnst pay a tax towards the support of those who go to war." "This address was cordially receired, and on the king requesting those who wished to rolunteer for service to stand up, a great number instantly arose.

The Officers of the Toromahery Regiment (the one disciplined body of the capital) ascertained the number of volunteors to be 13,000 , and these were at once placed in training and reviewed at Ambohimanga in March 1823. This small army was harangued by Radama, who 
left it to them to consider and determine what punishment should bo inflicted on cowards and deserters. The troops unanimously fixed upon barning as the military punishment for desertion and cowardice; this punishment, however, it was expressly agreed should not affect the family or property of the criminal.

It was not then imagined to what extent the power, which was created by a disciplined and organized standing armf, would desolate the country and destroy the inhabitants of the otber provinces of the island.

Establistment of the Ilova Power on the East Coast.-One of the first uses Radama made of his possession of a regular army was to establish a post on the east const and connect it by a line of communication with the capital. The eligible situation fixed upon was Foule Point, with communication through the Antsilanaka countrs.

The Second Salkaldica War.-In 1823 the war with the Sakaliva chief, =Ramitraha, was renewed, and Radama took the field with his 13,000 disciplined troops, accompanied by 7,000 bearers and camp followers, with baggage and prorisions. On arriving at the frontier, a mission was sent on in adrance, promising good terms to the Sàkalàva, who, however, rejected the message with scorn.

The first stronghold on the borders of Menabe is the rock fortress of Mlodongy (the Village of the Sulky). The inhabitants defended themselves with much bravery, but the place was stormed, many of the defonders putting an end to their own existenco rather than fall into the hands of the Horas.

Another engagement took place within the. Sàkalàra territory, and to show his determination to retain his conquests and to remain in the country, Radama ordered a party of 2,000 men to clear the site of the battle, and build $a$ village and stockade on the spot. Here he established a garrison, and left Rakizoarivo as Gorernor of the district.

This determined attitude caused Ramitraha to gire in his submission, and he therefore proposed that tho Hova King should enter: into an alliance with him by marrying his daughter Rasalima. This was agreed upon, Ramitraha acknowledged the suzorainty of Radama, and the latter returned with his Sàkalàva bride to the capital, accompanied by the representatives of Ramitraha, who swore allegiance and friendship in pablic assembly at Antananarivo.

Ifeantime Rafaralahy, Radama's officer at Foule Point, was threatened by a coalition of the malcontent chiefs of the northern provinces.' These chiefs were therefore summoned to swear allegiance, an order with which they were forced to comply, although they were secretly plotting a rebellion against the authority of the Hova supremacy.

This threatening appearance and discontent caused Rndama to march his army to the east coast, and he appeared before Tamatare, where his suzerainty was acknowledged by the half-casto chief of the Betsimisaraka, Jean Réné. Then he proceeded to Foule Point, where H.M.S. "Ariadne" was lying, commanded by Captain Moorsom. Captain Moorsom conreyed Radama and about 200 of his men across Antongil Bay, whilst the main body of his troops marched round 
through Maroa. Radama established his troops in various posts, and returned through Antsihanaka to establish direct communication with Imerina. The chief of the Antsihanaka, thinking himself secure on his island in the large lake Alaotra, refused to come in and give his submission, whereupon Radama constructed rafts on which he placed his cannon and attacked the island. The first assault was repulsed, and the Officer in command was tried by court-martial and burnt. Another attack was successful, and the island taken, upon which the subjection of the Antsihanaka was accomplished. Simultaneously another Hova Officer, Rataffe; procecded against the northern Sikalàra of Iboina, who accepted the terms offered by Radama: The Horas thus were'acknowledged supreme throughont the northern portion of Madagascar.

1824. Radama now felt that he had acquired his sovereignty by his,military power, that he must maintain his supremacy by the same méns, and that instead of leading into the field a lawless horde of rapacious savages, ho now commanded a disciplined force. Governor Farquhar, who risited Foulo Point at this period (1823), describes the garrison there as " $\mathrm{a}$ well-accontred, rer'y respectably-disciplined body of soldiers, whose condact and regularity in all their exercises and evolutions marked at once a considerable degree of sagacity, subordination, and senso of propriety.".

In the spring of 1824 , Radama, still boni on reducing every chief in the island to a state of vassalage, detormined upon undertaking another expedition into the north Sìkalàva country, leaving his capital on the 28th May.

B5 the 12th June tho army was encamped at Anaslaroor, when intelligence was received that Andriansolo, instead of delivering up the flag he lad received from Cummodore Nourse, was prepared to resist. Mr. Hastie went forward and attempted to make terms, but Hussan Barroched, the Arab. Commandant of Mojangà, rofused to submit, and was killed by the Horas, whilst Andriansolo took refuge on an island. Radama's Generals Ramanetaka and Rameno occupied IIojangà and put a stop to the slare trade carried on there by Arabs and Moormen; whilst after some delay Andriansolo camo in and submitted to Radama on the 19th July:

The prorince of Iboina sabmitted, and Ramanetaka, with a garrison of 1,100 men, was left to garrison Mojangà and to rulo orer the country from the river Manambolo to Majambo Bay; Rameno to gorem the country between the Betsiboka and tho Sofia rivers from his post at Trabonjy; Razatora to the north Antinkara district at Volémar; Ramarosikina to govern all Iboina mest of the Betsiboka.

Radama and a portion of his army turned south through the forest of Manerinerina between the Bemaríha Hills and the Bongo Lava Mountains, where there are quantities of wild cattle. Here the celebrated leader and sorceress Triemanosinamamy was captured and killed. In October the troops returned to Vonizongo and reached the capital during the following month.' "The whole island is now mine," said Radama.

1825. On the 1st Jannary, General Ramananolona left Imerina 
with 2,000 troops and took Fort Dauphin, remaining there as Gorernor of South Mradagascar. During the same year some thousands of troops were sent in detachments to garrison varions fortificd villages and posts throughout the conquered prorinces, and to enforce the disarmament of the inhabitants. The Sàkalìv, howorer, again rerolted, cut off and massacred sercral of the garrisons, whilst Andriansolo refused sabmission to Ramianetaka, and fled to an island on the coast. It was only by great exertion that Ramanetaka was able to hold Mojangì until General Rainimaka joined bim with reinforcements and suppressed the rebellion.

General Rafozehana at the same time led a division of troops throngh Menabé in fruitless search for Ramitraba, disarming the tribes.

In June, the districts of Maroa and Betsimisaraka rerolted. the inhabitants refusing to surrender their fircarms. Mrr. Hnstio suppressed Maroa, and Rafaralahy restored tranquillity among the Betsim.saraka. Andriandina at this time sabdued the cnuntry of Anonibe cast of Antongil Bay, although nnable to make the chief, Isasy, prisoner.

1826. Rafozchana was again despatched with troops through M[enabé in 1826, searching for Ramitralia, whose daughter, Rasalima, was also sent to treat with her father, accompanied by an escort of 1,000 Horas under $\mathbf{M}$. Robin. A nephew of Ramitraha; attempting to surprise the escort of his cousin, was killed, and the Sàkalàra chief sent an embassy to Radama, thus prerenting further hostilities.

In June Radama procecded to the const at Tamatare, whilst General Brady left the capital with an army of 9,000 troops and 5,000 bearers

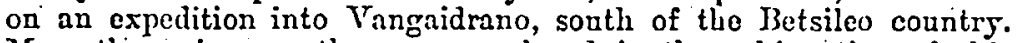
Wore than nine montls rere employed in the subjugation of this difficult country, where erery rillage was a natural fortress, and tho opposition formidable.

At last Rabedokn the chief was captured by stratagem. He and several of his principal adherents and their followers had taken up a position at Hiàranàng, where they bravely defended themselves. Unable to take the place by storm in open daylight, the Hovas collected a quantity of strat and drs grass, with which they constracted n number of bonfires. Suddenly lighting theso bonfires by night, they made their attack on the superstitious savages, who were terrified by the nnforeseen fircs, and fled down the ralles of the Mandianafotsf, where the survirors submitted inconditionally the following morning. Rabedoka and twenty of his chiefs were slain, their bodies being exposed on poles at the entranco of his town.

On the return of the troops sereral Officers and men, haring been convicted of cowardice, were condemned to death and publicly burnt alive.

Ralahifotsy, who was in command of a force checking insubordination in Betanimena and Antera, was also convicted of defrauding the King of captared spoil, and with his colleague Rafaralahindera suffered death by being shot.

On July $27 \mathrm{tb}$, 1828, King Radama died, haring firmls established Hora supremacy throughout the island of Madagascar. 
1828. Military Despotism of Queen Ranavilona I.-The principal man in all the erents that conducted Ranavàlona $I$ to the throne of Madagascar was the joung Officer, Andrianmihaja, who had preriously distinguished himself in the wars against the Sàkalàva nnder the late sopereign. He was immediately chosen on his accession as Prime Mlinister and Commander-in-Chief.

Radama, as already intimated, enlarged his kingdom of Imerina by conquest, until he had obtained more than half the island. To secure these additions, and ultimately carry ont the predetermined plans of Radama by subjugating the whole island of Madagascar, was now the principal object of Ranavàlona's government.

For: this purpose the attention of the Horas was chiefly directed to annual predatory excursions and raids, such as had been the customary system of warfare thronghout the island from time immemorial; bnt the Horas had now appreciated organization and reaped its audrantages, so that these annual raids had become a systematic method of obtaining revenne for the Hora sovereign. In fact they were military expeditions ostensibly for enforcing the sovereignty of the Horas over the less civilized tribes, and disarming the rebellious populations; bat in reality the commanders of the Qucen's forces gained credit by returning with as mnch spoil, in the shape of slares and oxen, as they could capture to the capital; enriching their sovereign and themselres indeed, but derastating and depopnlating the richest districts in the island, and imporerishing as well the province of Imerina itself by draining it of its jouth for the great standing army amounting to no less than from 20,000 to 30,000 men. As large numbers perisbed annually from disease and exposure during these enmpaigns, new levies had constantly to be mado until the flower of the Hova people disappeared.

These warlike excursions for the purpose of subduing the provinces that had not submitted to the Hora rule were attended with melancholy results and cruelties abhorrent to humanity. A division of the army, amounting to perhaps some 2,500 or eren 10,000 men, as the circumstances of the case seemed to require, was despatched about the close of the raing season, in June, to the selected locality with orders to return home before the commencement of the rainy season "in October or November. This army was attended by a large following of non-combatants ready to share in the opportunities for plunder. No regular commissariat or system of supply existed, and the troops and camp followers lived apon the country through which they marched like a flight of locusts.

The first military operations, howerer, in which the troops of Ranavalona had to participate were of a defensive character, as the French Government had determined to enforce its rights at the hands of the newly constitnted Malagasy Cabinet.

Gourbeyre's Expedition, 1829-30.-Early in 1829 the Gorernment of Charles $X$ decided that a squadron should make a demonstration off the coast of Madagascar to ascertain the feeling of the new Queen of Madagascar and to uphold French interests.

The then Minister of Marine, M. Hyde de Neurille, accordingly 
notified this decision to the Count de Cleffontaines, Gorernor of Réunion, impressing on him the necessity of only occupying such points on the coast as could be safely held by the troops available.

In accordance with the Minister's instructions the following vessels were collected at Réanion and St. Marie in June, whence thes assembled at their appointed rendezvous in the roadstend of Iamatare on the 9th July, 1829, viz.:- "La Nièrre," "La Cherrette," "L'Infatigable," "La Terpsichore." Theso were joined by the transport "Mradagascar," carrying expeditionary land forces as follows:-85 artillery, 21 military labourers, and 33 infantry (including Yolofs, black troops from Senegal). Capitaine de Vaisseau Gourberre arrired in the despatch ressel "Colibri," and hoisted his broad pendant on board the frigate "Terpsichore."

The French Commodore landed with presents for the Qucen, in order to ascertain the dispositions of the Hova Government, and observed that preparations for the defence of Tamatave were being made, the garrison of the fort boing increased, and ammunition arriving from the interior.

MI. Gonrbeyre therefore at once despatched an ultimatum to Queen Ranavalona notifying the French complaints, and demanding an answer mithin twenty days. Meantime the squadron proceeded north to Tintingue of which possession was taken on the 2nd Augnst, and here earthworks were at once thrown up, armed with eight guns, and garrisoned. The small fort was occupied, and the French colours hoisted on the 19th September, without resistance.

About this period the French deserter Robin, who had served with Radama, came to M. Gourbeyre to offer his services in raising the Salkalàva tribes of the north-west const, under the exiled chief Ramanetakn from Anjouan : but M. Gourbeyre would not entertain the project.

Leaving the "Infatigable" corvette at Tintingac with 300 men in garrison, the Commodore took the rest of his force to Tamatare, where he moved his ships within easy range (300 toises) of the Hora battery, Taomasina, by the 10th October. Having sent on shore to the Hova Chief, Coroller, to know if the Queen had sent down the necessary authority for him to treat with the French, on a reply to the negative effect being received, the French Commander sent a formal declaration of war and intimated that he would commence lostilities immediately. The first few shells fired were sufficient to explode the powder magazine of the fort, upon which the Hova garrison abandoned the works, and 238 men under Captain Fénix landed and took possession of the place, finding 23 carronades and 200 muskets left behind with 50 bodies of Hova soldiers slain by the effects of the French fire and the explosion.

M. Gourbeyre did not occupy Tamatare, but proceeded to Foule Point, where the squadron anchored on the 26 th October.

On the 27th the ships opened fire on and silenced some batteries on the coast, and landing parties were put on shore to spike the guns and take possession of the village, in rear of which the Horas had. constructed a retrenchment.

YOL. xxix. 
Disaster at Foule Point.-The French (writes 11 . Barbic du Bocage), ${ }^{1}$ having seen the Horas evacuato their battories, extendecl themselves without orders on the beach, discharging their muskets at the fugitives and pursuing them with the bayonet. Thus ther traversed the streets of Foule Point; but on reaching the furthest huts they found themselres in front of a new redoubt whose existence they had not suspected. At first sight they attempted to form a column of attack whilst the Yolofs should make a détonr round the enemy's flank under Captain Scholl, but by some fatality whilst rallying, the Horas discovered them and discharged grape and canister from soren or eight guns in the redoubt, which fire caused disorder and loss in the ranks not yet re-formed. A panic ensued and the soldiers fled to the shore. The Hovas seized this opportunity to make a sortic and would have infallibly cut off the retreat of the French troops, had not Ensign Charuau, who commanled the frigate's catter, fired case into them with the boat's gun. 'Unfortunately Captain Schœll was killed, together with five or' six French sailors. In this disastrous affair the Horas were said to lave lost 75 killed and 50 wounded: whilst the French loss was 11 kilied and 26 wounded: but this difference, says MI. de Bocage, did not diminish the mornl effect of the ront, and the Hovas naturally exaggerated their victory.

Commodore Gourbegre did not attempt to make reprisals or repair the repulse of his force on shore, bnt withdrew to Tintingue, which fort was threatened by the enemy. 'Thence he proceeded against a post which the Hovas had established at Pointe à Larrée, which he attacked on the 4th of November. Here, reinforced by 50 artillerymen and 20 Yolofs from Tintingue, the French squadron bombarded the fort for tro hours, after which a storming party in two columns was landed and led to the attack by Captain d'Espagne. The right column advanced and penetrated the fort by one entrance, nnder Lieutenant Baudson of the artillery, who fell covered with wounds. The left column under Lieutenant Somsois, Mrarine Artillers, and MI. Dambané, succeeded in forcing their entrance at another gate, and the fort was taken. The Hovas left 119 dead on the ground, 27 prisoners, 8 guns, 700 pounds of powder, and 250 oxen. The French loss was one dead, and nine wounded.

The season was now at an end, and the French squadron was withdrawn, leaving a garrison of 400 men under Captrin Gailly, at Tintingne, and 150 men under MI. Carayon at Ste. Marie, the intention of the Gorernment being to prosecute the compaign with vigour during the next good scason. Tho Rerolution of July at Paris overturned the French Government and the policy of M. Hyde de Nenville.

General Sébastiani and Vicomte d'Argont, the new Minister of Mrarine, shelved the Mradagnscar question, and in Mray, 1831, the eracuation of Tintingue was effected in the face of a force of 3,000 1858.

1 "Madagascar, Posecssion Française depuis 1642 :", par V. A. Barbié du Bocage, 
IToras, who at once took possession of the place. Ste. Maric was still held by the French, and has since remained a French colony. T'Le French did not again hold auy port on the mainland of Madagascar for orer half a century.

During all these operations in 1820 , it may be remembered that the coast tribes held aloof from the French and could not be persuaded to rise agaiust the Horas, their masters. They are still the same that thes were in tho days of Flacourt, of $\mathrm{La}$ Case, of Benyowshi, and Hastie, mistrustful of Europeans, and advisedly so.

1831. Expedition of Rainiharo and Ramboasalama.-Among some of the carliest expeditions sent out during the Queen's reign were those under the conmand of Rainiluaro and Ramboasalama to the soutb in 1831. These chicfs on their march southwads came to a town in the Betsilco country, and determined to. sacrifice it for the sake of plunder.

There werg about 300 families residing there, living in quict and peaceable sufmission to the Hovas, regarding them as friends, and never dreawing of attempt to escape on the approach of the arms.

'The Officers of the Queen's troops then invited all the men from the village to a friendly repast with them in their camp; and the iuvitation was accepted. The soldiers had private orders given them to be provided with lnshings, and that as soon as they heard the drum beat thes should scize and bind their gacsts. At the appointed hour the unsuspecting rillagers arrived, entered the camp, and sat down quietly waiting for their cooked rice; when the drums were beaten, and at the signal the soldiers seized their visitors, bound their hands, and leading them outside the lines, deliberately speared them in cold blood. 'Tlie second Oflicer in command on this ocension, Ramafadrahona, boasted that ho had killed eleren of them with his own hands.

One of the villagers who happened to remain at home, hearing what was taking place, effected his escape to Ikongro, a vatural hill fortress, about 60 or 70 miles from the scene of treachery. Here several Betsileo and Tanala chieftnins collected, and many thousands of their people. As soon as they heard the fate of the man's companions, they determined to accept no terms from the deceitful Horn, but to defend their mountain home to the last.

'The Hovs army arrived outside Itongo in three days. Ono division of it was told off for the attack under Ramafadrahona, with instructions to retreat for the day at four o'clock if the place were not taken by that time. The single path that lads up the mountain is excecd: ingly narrow, and leads orer a tremendous precipice. Close to the entrance to the village is a piece of level ground, which the Ifova soldiers at last reached with their gans and opened fire on the de: fenders, who conld only reply. with stones: Meantime a large number of non-combatant followers had got in adrance of the troops reads to rush in and scize the plunder as soon as the troops advanced. But when four o'clock arrired, tho order was given to withdraw the guns and descend, upon which the camp followers, dreading their being left unprotected against a sortic of the Ikongo, made a rush to gain 
the narrow pathway, and a panic took place; the Officers, soldiers, and mob of camp followers and bearers pressed one another indiscriminately pell-mell over the precipice, where it is said that not less than 2,000 Hova perished. Among them were Ramafadrahona binself and his second in command, Rafalimanana. When the Ikongo tribesmen at length ventured out, they rere astonished at the numbers that had perished, and the quantities of muskets and spears, besides the two guns, which they took possession of. This attempt to take Ikongo failed; the Commander of the Hova forces returned to Imerina for reinforcements, but it does not appear that Ikongo was ever captured, and it yet remains in possession of the Tanala tribesmen.

Another Hova expedition, under Raralontsalama, proceded into the Sàkalàva country to the west, the same jear, and although more successful as to booty, the methods emplojed were not less cruel and un. principled than those just mentioned. The chiefs of a district in Menabé were accused of concealing firearms. This was a mere pretence. An appeal was mado to the ordeal of the Tangena poison, and of course it convicted the parties whom it was intended should be convicted. All the principal men that conld be found were seized and thrown bound into a deep excavation dug for the purpose, and after being kept there about two days without any kind of provision, were taken out one by one, and actually crucified at short intervals from one another, forming a long line of excruciating agony round the chief village of the district. It is recorded that many of the wives and female relations of the victims refused to submit to their hard fate of slavery, cruelty, and insult. "This," said they, " is the land of our fathers, our husbands, and our brothers, whom you have murdered in our sight, and shall we now accompany yon far away to Imerina to live and die as slaves there?" The spear soon silenced their complaints, and they perished, as they desired, on the spot. Some thousands of the Salkalava were, Lowever, seizcd as booty and convejed to Imerina by the Hova troops.

1832. Barbarous Cruelly at Ivato.-A most revolting instance of barbarous cruelty occurred again in 1832, when Rainiharo and Ramboasalama headed an expedition of $10,000 \mathrm{men}$, with as many camp followers, to the south. When they reached Irato, a rillage in the Manandriana division of the Betsileo country (lat. $20^{\circ}, 32^{\prime} \mathrm{S}$., long. $47^{\circ} 20^{\prime} \mathrm{E}$.), they found the people posted on a hill, prepared to fight in defence of their homes. The village is almost inaccessible, and within it were ten or twelve powerful chiefs with their clans. The wily Generals, finding it would be almost im. possible to take the village by force, employed stratagem, and endearoured to persuade the people to sabmit, promising in the strongest terms that if they would quietly deliver up their arms no one should injure them. 'I'his negotiation was carried on for three days. At length a division of opinion arose among the Betsileo chiefs, some of whom were disposed to. place confidence in the Hora promises, others strongly resisting a measure so full of danger. One ond of the rillage was connected with a large forest, and the latter 
party made good their escape through it during the night. $A$ bont 20,000 persons, howerer, remained, and these deluded wretches, after arain being assured of the most friendly dispositions towards them, delirered up their arms, spears, and muskets.

They were then surrounded by soldiers, and all the men found able to carry a spear were ordered to pass from one circle of soldiers to another, while the women and children remained within the first circle. They were ench carefully examined as they passed between the soldiers to see whether they had any concealed reapons upon them. The soldiers then commenced tying their hands behind them, when their fate was evident. Those not yet bound made a desperate rush through the ranks, and some few who tried to escape were caught outside and billed at once. Those that were bound were killed at leisure the following day, the massacre commencing early in the morning and lasting until late in the afternoon:

The expedition then returned to the capital, flushed with their success at the shambles, bringing 13,000 captives. MIultitudes of thein, filled with grief and horror at the fate of their husbands and fathers, refused to eat on the road, and suffered for it by being beaten. Those who remained inflesible were speared with those who from illness wero unable to keep up with the troops. Grief, fatigae, and famine destroyed many long before the capital was reached, where the survivors were sold to the highest bidder.

In 1833, Ratsimanisa conducted an expedition to the south, killed many people, and returned home with 2,000 captives. Ho administered the ordeal of Tangena to four chieftains, pretending to ascertain thereby their intention of rebelling against Ranavalona. Three out of the four were convicted, and of course put to deatl with all the able-bodied men in their respective districts, the women and children as usual being made captives and sold into slarery.

Sereral other expeditions were sent to different parts of the island this same year, and their operations were of the same outrageous character.

In 1834, troops were again despatehed to the south, when they destroyed an immense number of the people, and returned home to Antananarivo with about 10,000 captives.

In 1835, a large expedition was despatched to the south-west, to the vicinity of St. Augustine's Bay, under the command of Rainiharo, Andrianisa and Ratiaray being the Officcrs under him.

There were about 10,000 or 11,000 men in this affair, accompanied by an unusually large number of non-combatants, making a total of not less than 30,000 or 40,000 . After advancing beyond Fianàrantsoa, the capital of the Betsileo, a large part of the troops and people being without provisions, were permitted to requisition the property of the peaceable inhabitants, who were the acknowledged subjects of Ranavilona, so that multitudes were left without any support for the remainder of the year and perished of famine.

The main body of this army proceeded to Mahafaly, thence to Taboara, and across the River Onilahy. Here the army separated; Rainimarolahy and Rakodia took 2,000 men to the west, and Andria- 
maro and Rasoarivo with other 2,000 to the cast, Ramazava with 1,000 men to the north, and Ramandranto with a similar number to the south. On the return of these divisions from their reconnaissance, a large camp was formed on the north bank of the Onilahy River, whilst 6,000 troops were sent sonth to Andriampierenana and Andriamahaka, under Razakandrianaina, Ratsitohaina, and Ravelo (all 11 honours). Raningory (11 honours) proceeded with a party down the Onilahy to the port of Isalary. Here they found a fleet of twentyono American whalers, at sight of which the Hovas were greatly dismayed, and the whole expedition retired to Imerina, expecting au invasion of foreigners.

In 1836, Ratsimanisa was despatched with 6,000 troops to the south, Rainingitabe with 2,000 to the north, and Ravalontsalama with 3,000 to the west. All these returned home in September or October. Ratsimanisa had destroyed upwards of $4,000 \mathrm{men}$ in one day, and carried home with him upwards of 9,000 captires.

On the arriral of Ratsimanisa in the Betsileo country, messengers were sent out by him in every direction to invite the people to assemble, and to assure them that he was only sent by Ranavalona to administer to them the oath of allegiance and to take their arms, which they must deliver up to the Queen.

Hafing thas collected all the inhabitants that he could, he divided them into three parties, the first consisting of adults capable of bearing arms, the second of youths about 4 feet high, and in the third he placed all the women and children.

The first party of men were then all bound, a ceremony insisted on and too tamely submitted to, as a form in which they were to take the oath of allegiance. They were then ordered, to accompany the soldiers to a large swamp, where the oath was to be administered by striking the water. On arriving at this spot the drums beat a signal, and erery one of the adult natives was put to death by the spear. An examination was then made of the youths, and all who were found to be even half an inch abore the given arbitrary standard of stature, which the Officers carried with thom by the Quecn's instructions, were placed by themselves, and soon slared the fate of their fathers. The cries of the women and children had no effect upon the ruthless conquerors. On his return home Ranavàlona highly praised Ratsimanisa for his consummate skill and success, observing that she had no Officer to bo compared with him in capturing slares and booty.

Rainingitabe returned from his raid to the north with about 1,000 captives, after putting to death uprards of 400 men. He had cncountered a pretty smart struggle with the Boeni Sàkalàva, and many had fallen on both sides.

Ravalontsalama, having killed about 400 of the enemy in Menabe, returned home with 700 captive Sàkalàva women and children.

These details are sufficient to illustrate the military character of the gorernment of Quecn Ranaràlona which thus desolated the whole island, and proved as ruinous to the Hora themselres as to the provinces they subjugated by the method of merciless extermination of all the adult males. 
1837. Olose Investment and Caipture of Itsàranóro.-Itsàranóro is now but a swall village in a valley on the borders of tho Betsileo and Jara countries south of Tsi-afa-batála (not to be climbed b!y grasshoppers), on a rounded boulder-topped hill corered by a smail wood. Although now bot a few huts remain, in the dass of Rannvilona I the place could bnast of a large population. During the reign of that Queen in 1837 liamiándrirólo (15 honours) brought Hora troops against the place, and nol being ablo to take it by assault, regularly invested it until the occupants should be forced to surrender.

The iuhabitants preferred to die of starration rather than submit to the mercies of the Hova soldiers, and carricd out their determination with Spartan stoicism. When at length tho Hova troops entered the town of Itsàranóro orers human being and aninal was dead. Eren uow the rocks are full of human bones.

The countres was now closed to all communication with the outer world, but we know that the nnnual raids against the weaker tribes continued. It was, in fact, the normal mode of collecting rerenue. The only European who was resident at the capital was one M. Iraborde, forperly an artificer in the French Arny, who greatly cnriched himself in property and slares by manufacturing arms for the Hora troops.

$\Lambda$ recoid of the building of the great palace at Antananariro, howerer, furnishes us with the numbers of the troops emplored as military labourers in 1839. These are the numbers of the trops that wero lrouglit for the work :-

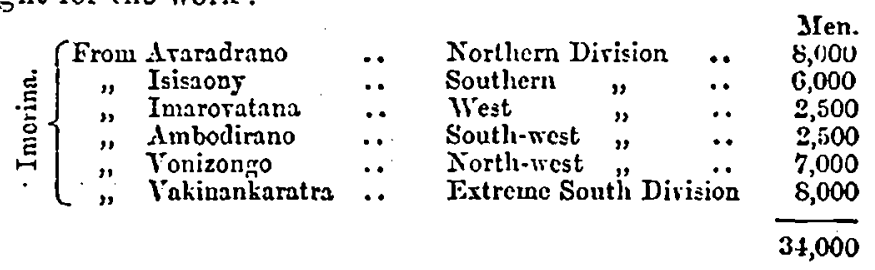

It was stated in $18+0$ that the prorince of Ankora (Imerina) had been drained of its youth to maintain the stauding arms of 30,000 to $40,000 \mathrm{men}$; that in their expeditions which were atteuded by a more than equal number of camp followers, scarcely more than half the number returned. But this almitted of no comparison with the numbers that perished by the treachery and carnage of these troops. It is stated that at the above time 100,000 human beings had been killed in Queen Rannràlona's wars, and double that number, inclading women and children, sold into slarery, or dirided as booty among the Onicers. The Queen's Gorerument now thought that their forces would be as efficient against foreigner's as they had proved against their own neighbours, and the arms, which included the large proportion of the manhood of Ankora, was increased. ${ }^{1}$

1815. Disastrous Attacli on Tamatave by the Allich Squadron.-

' George A. Slam, "Antananarivo Annual," 1870, p. 101. 
In consequence of complaints made by British subjects to the Gorernment of Manritius in 1844, Her Majesty's ship "Conway," 26 guns, commanded by Captain Kelly, was despatehed to Tamatave, with instructions to call upon the authorities there for an explanation of the circumstances which had led to the infliction of imprisonment and fine on Englishmen. No satisfactory result onsued, and the "Conway" returned to Manaritius for further orders, when suddenly a peremptory order from Queen Ranaràlona arrived, ordering Razaliafids, the Governor of Tamatave, to expel all the European traders from the island.

Lientenant.General Sir William Gomm, Governor of the Mauritius: and Admiral Baroche, Governor of Réunion, on hearing of this hostile move by the Hovn Gorernment, at once tuok steps to protect the European merchants on the coast of Madagascar. Accordingly the "Conway" anchored in the roadstead off T'amatare on the 12th June, where the "Zélée," 12 guns, commanded by Captain Fiéreck, had already arrired, and on the same day, the French Commodore, Romain Desfossés, made his appearanco in the "Bercenu "frigate, of 26 guns.

During the 13th and 14th the Europeans were embarked on board the worchant ships in the roads, under protection of the guns of the men-of-war, but their houses were plundered by the Mlalagasy, an outrage which the English and French Commanders, who were in complete accord, resolved to punish.

On the morning of Sunday, 15th June, therefore a joint protest against the proceedings of the Hova anthorities was sent on shore; with a notice that fire would bo opened from the ships unless a satisfactory answer. was received by 2 p.M.

The Hova soldiers retired into their fort, and the inhabitants fled from the town in expectation of the attack.

The allied ships were moored in a line parallel to the shore, opposite the Malagasy works, at a distance of 700 yards from the principal fort.

The fortified works of Tamatave consisted of two elevated batteries with guus en barbette and open in rear, connected with and flanking the principal fort, an enclosed work of considerable streugth, which had been built under the direction of two Arabs of Zanzibar, subsequent to the expedition under Captain Gourbegre in 1829, and only lately completed. 'This fort, which still remains, is of peculiar construction, and consists of a circular citadel, with massive rampart and parapet of coral rock, in which are casemated galleries and embrasures. Round the body of the work is a dry ditch, 32 fect. broad, and perpendicular scarp and countersearp. On the crest of the countersearp is an outer enceinte, forming another parapet with largo ports corresponding to the embrasures of the inner and main work. The exterior slope of this parapet at an angle of $45^{\circ}$ is strongly palisaded, and the whole thickly screened bj groves of trees and bushy scrub, down to the beach.

The garrison at the time was estimated at 400 regalar Hova troops, with 600 Bestsimisaraka and Betanimena auxiliaries. 
At noon Captain Desfossés (whose official report is followed) harangued his crew, and informed them and the French refugees that the Hovas were to be punished that day; whereupon the refugees requested permission to be armed, and were furnished with muskets and cutlasses, $\mathbb{d c}$.

At two o'clock the answer to the altimatam arrived from Razakafidy, the Governor, who expressed the intention of his Government not to rescind the offensive proclamation, and within five minutes afterwards fire was opened upon the fort from the guns of "Le Bercean " and the "Conway," whilst "La Zélée," at the head of the line, directed her fire on the flank battery to the south.

The fire was returned from the Hora batteries, not very energetically, but with astonishing precision, their artillery being directed, according to Mr. Desfossés, by a renegade Spaniard. After firing had gone on for a quarter of an hour a violent conflagration in the vicinity of the northern battery bore witness to the effect of the shell; and by half-past three, as a great number of shell had been observed to burst within the fort and other battery, it was considered by Captains Kelly and Desfossés that a large proportion of the defenders must have been destroyed, and that it was time to land some detachments to take pussession of the place, and terminate the operation before erening set in. Accordingly, 100 sailors and 68 marines of the "Berceau," 40 sailors and 30 marines of the "Zélée," with 80 blue-jackets and marines of the "Conway," were embarked in 14 boats in perfect order, forming a line parallel to the shore, the English on the right, the "Bercean" in the centre, and the "Zélée" on the left.

At a given signal the boats proceeded simultaneously under corer of the tire from the ships, and the combined French and English force landed and formed in order of attack on the beach at 200 jards from the fort.

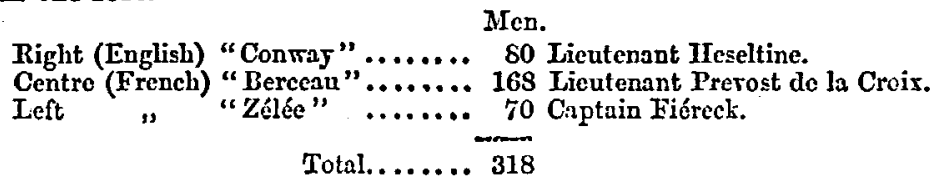

Two small howitzers on mountain carriages were taken by Lientenant de la Croix, and brought along in the centre.

The Horas contented themselres with firing some rounds of case during the disembarkation which produced bat little effect, and the combined force ad ranced at a quick pace against the "Malagasy" work, which was in a great measure screened by thick groves of bushy trees. Some men of the "Zélée," with others of the "Bercenu," under a midshipman, gained the south battery, where they spiked three guns, overturned two others, and drove its defenders into the principal fort, which the French in vain attempted to enter with the fugitives. Whilst the south outwork was thus captured the main body marched straight ap the glacis and outer slope of the enceinto and cromned the covered way, thinking it was the fort itself they had 
thus taken; on reaching the summit the mistake was apparent, there was a broad deep ditch between them and the body of the work; the escarp of which was 30 feet- high, and the attacking party had brought no scaling ladders. The assault failed inevitably. From their casemated galleries the Hovas were able to firo on the allies, who maintained possession of the oniter works for forty minutes, when, their a mmunition failing, Captain Desfossés sounded the recall on the beach and the various detachments retired and, re-forming in their original formation on the shore, re-embarked with their guns, their killed and wounded, at least the majority of them.

Repulse at Tamatave.

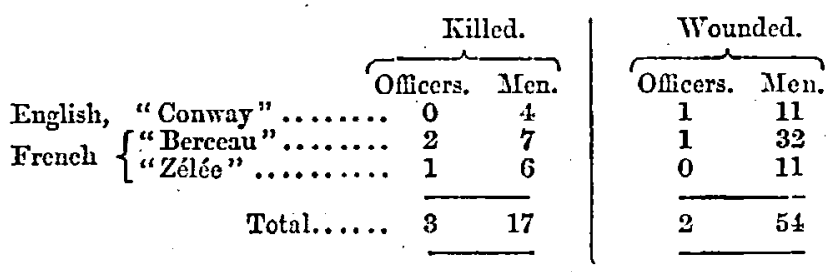

Total casualtics : Officers, 5 ; Men, $71=76$.

The "Berceau" was struck by thirteen shot; one of which broke tho fore topmnst. The "Zélée" was also struck several times and also had her topmast cut. Unfortunately, thirteen bodies, which could not be carried off, were left in the hands of the enemy, and when the expedition sailed away, the sailors could see the heads of their comrades fastened on poles along the beach, where they remained for nearly ten years, until the merchants of MLauritius and Réunion subscribed 3,125l. for the renewal of trade in 1854, when the heads were taken down and interred at Ste. Marie. . Thus ended this unfortunate expedition, which was not renewed, the policy of the Governors of Mlauritins and Rénnion being disarowed by their respective Governmeuts in Europe.

This effective repulse of the two great marine Powers by their fort at Tamatave naturally gare great impulse to the military pride of the Hovas, and encouraged the old, or what may be termed the idol party, to keep aloof from all exterior intercourse, and, in consequence, Imerina, and indeed all Madagascar, was closed to Europcan influence for a period of nearly twenty jears.

1819. Insurrection at Nosi-Bé.-An attempt to drire the French out of Nosi-Bé was made by the Sàkalàva in June, 1819. The Sàkalavì Chiefs, Linta and Tsimandroho, who had ceded Nosi-Bé to the French eight jears previously, left the island, and the Sàkalàva assembled at Ankify on the mainland opposito Hellville at the end of June, and landed during the night in considerable numbers on the island. The small French force arailable consisted of sixty Marine Light Iufantry and 800 liberated slaves, who however could not be depended upon and were armed only with spears. The only Officer, a Lieutenant of Marines, was unfortunately 
shot whilst making a reconnaissance, whilst the garrison held an entrenched position defended with two small gans in a sand-bag batterg. At daglight, the Salakiva delivered their assault, led by some twenty or more of their Ombiasy and fanatics. They were permitted to adrance close to the guns, which being suddenly unmasked fired two rounds of case, by which thirty-two of the Sàkalàva were killed, upon which the sarages fled and left the island precipitately. On the following day reinforcements arrived from Mayotte, and the Colony was placed in a state of defence.

1851. Sálalazd Raid on 'Tafondro.-After the Silkalàra revolt of 1849, Tsimandroho again took up his residence under French protecticn at Tafondro, in Nosi-Bé. But in April, 1851; a party of 500 Sikalìra crossed over from the mainland, and orercoming the small French post, killing the corporal in charge, murdered Tsimandroho, cut off his head and carried it off as a trophy to their country at Morontsanga.

The Commandant of Nosi-Bé sent over 600 Sàkalàva allies to punish their compatriots. But on reaching Mlorontsanga, they found the place desercted, so they burnt the village by way of reprisal.

1856. The liffair of Baratoubé.-A French factory was established at Bavatoubé by $3 i$. Lambert on the coast at the entrance to Passandara Bay, almost immediately opposito to Nosi-bé, the French Colony before mentioned, in 1855. Throughout the locality deposits of bitumen and mineral oils were exploited for nearly twelve montlis by the employés of Lambert's company, who constructed buildings and fortified the station with a regular rampart and stockade with five ships' guns mounted in position, whilst a number of Mozambiques, i.e., slaves, were armed, and the position was deemed well defensible and able to hold out in case of any attack until assistance could arrive from Nosi-Bé, which is within signalling distance, and where a French man-of-war is generally stationed. M. Lambert placed M. d'Arroy, formerly French Consul at Port Louis, in charge of the establishment, but the Hova Government warned him, when the former departed for Europe in 1856, that having learned of the armed occupation by a forcigner of a position at Baratoubé, he would remain there at his peril. II. d'Arroy seems to have trusted to his armed retainers and defences and remained at his post. Accordingls, on the 19th October, a force of Hova soldiers proceeded to Bavatoubé, and M. d'Arvoy refusing to surrender, the place was surrounded and captured. II. d'Arroy and a number of lis followers, Creoles and Sakalàva, were slain. The Hora commander took 100 of the employés prisoners to Antananariro, with the guns, muskets, and a quantity of ammunition; the place was razed to the ground and has not since been occupied.

This affair, eleren years after the unarengcd repulse at Tamatare, naturally rendered the Chiefs of the Hova Government still more arrogant in their dealings with Europeans.

1859. Bombardment of Mrahogoulou.-The constant shipment of so-called free labourers (engages) from Baly Bay on the north-west coast led to sereral disastrous revolts on board the French ships. 
In one instance, in 1859, the "Marie Angélique" wns on the point of sailing for Réunion, when the Mralagasy un board attacked the crew, who jumped overboard and swam to a neighbouring ressel, ran the "goëlette"" ashore, burnt and pillaged her.

On this erent becoming known at Nosi-Bé, Captain de Iangle took his ship "La Cordelière" and anchored off MInhogoulou, the village of Outzinzou, in Baly Bay, on 13th February, 1859. A boat was sent on shore to bring off the Jesuit Missionary Fathers, and attempts to negotiate rere made in rain. The French boat was fired upon by the Sàkalava, who deserted their village and took to the woods. Whereupon the guns of the "Cordeliere" opened fire, and with a few rounds of shell destroged the rillage of MIahogoulou.

Six montls' afterwards the "Cordelière" returned, found the village rebuilt, and exacted a fine of 14,000 dollars, which fine was paid in cattle.

1861. Tho border lands between the Hora and Sàkaliva peoples at this time were desolate. Long tracts of country, twenty or more miles in width, were destitnte of inhabitants, and the Hova villages, as weri as those of their allics, were, even with that width of open neutral territory, never safe from night surprises and assaults, in which the cattle were driven off, the men killed, the women and children hurried into slavery, and the village left a heap of blackened stones and ashes.

At length the Queen died, in 1861; and her son, Rndama II, came to the throne. The new King had been thoroughly disgusted by tho sanguinary scenes of his jonth, and his first act was to proclaim that the soldiers should only muster once every two months, and he also at once reduced the fanompoana or service required of the noncombatants.

The next act of the liberal-minded Sorereign was to set free all the Sàkalàva captives. Ho then. sent all the Sàkalàva chiefs in the Hova power back to their conntry loaded with presents and messages of goodwill to their people. He also sent what they would esteem more than any gift, the bones of the chiefs who had died in captirity, that they might be buried in the tombs of their ancestors.

The Sàkalàra, who bad lately plundered a portion of Tonizongo, at once reinstated their captives and restored what property they could. Embassies under selected chiefs of the Sàkalàra were sent to Antananarivo to accept the welcome friendship and to cffer alleginnce to the King and Hova Government, the tribes along the whole line of conntry, with scarcely an exception, following this example. Radama II received these embassies with frank good nature, fensted them, and dismissed them. with presents to their homes. They offered to surrender their arms. "Keep them," he said; "when I want your help, jou will havo them reads."

The Sàkalàva agreed to furnish recruits to the Horn Army. The Hora people extended to the west, the Sàtalàra to the east, and occapied tho adjacent no-man's-land; the inhabitants interchanged risits and peace prevailed throughout the conntry. 
Iievolt of the Silialiva.-In May, 1863, the unfortunate Radama was slain in the course of a palace revolution.

The Sikalìva heard with indignation of the death of Radama, who was their friend, and at once invaded Vonizongo, killing some herdsmen and driving off 800 oxen of the Prime Minister of the now Gorernment. They remembered the ravages they had suffered dnring the former Queen's reign, and expected their renowal under Rasolerina; they therefore collected their forces and invited other tribes to join them in a march on the capital to arenge Rndama's death and destroy his murderers.

No message of peace or friendly explanation of the cause of the revolntion and change of Government was sent by Rainivoninahitraniony, the Prime Mrinister, to these tribes in revolt; but a force, accompanied by some guns, was despatehed under the command of one of the chief actors in the recent coup d'etat. The asual Hova strategy was employed, viz., treachery. The Hora force mored quickly before the allied tribes could collect, and after proposing negotiations, in order, as they said, to draw them together, attacked them, opening fire upon them from their artillery, which was masked, until the Sàkalàva were cut off from retrent. The Hova commander reported 2,000 slain, and returned to Antananarivo, followed by a long line of captive women and children and herds of cattle. Rasoherina, howerer, sent backthe captives and recouped the Officers and men with money.

This act of clemency by Rasoherina had no immedinte effect on the Sàkalìra, in consequence of the carnage and treachery by which it had been preceded. They declared they would make no peace with the murderers of Radama.

The country continued to be unsafe, and the inhabitants of Vonizongo had to betake themselves to their fortified villages.

Preparations to invade Imerina from another quarter were at the same time threatened. The Antsibanaka and the Ibouèni Sikalàva assembled on the northern borders of Imerina, and the Governor of Ambohimanga collected a Hova force to oppose them. Neither party, howerer, crossed the frontier; negotiations were carried on, and an arrangement entered into, rithont bloodshed, and peace has been anbroken since in Antsihauaka and the north.

The whole island of MIndagascar was now considered as but one kingdom, and it was considered necessary to maintain a comparatively large standing army to occupy the garrisons and posts on the frontiers, and at the ports, their chief occupation being the collection. of taxes and the prevention of smaggling.

Mrodern Reforms.-During the fire years of Queen Rasoherina's reign (1863-68), no special energy was shown in direction of military organization, and the army appears to bave then become less efficient than formerly. In consequence, some of the Sàkalàva and Anosy tribes, only nominally under Hora authority, became restless and even. threatening.

On the accession of Ranavalona II in 1868, under the present energetic and able Commander-in-Chief, Rainilaiarivony, the attention of the Government was turned to the reorganization of the army. 
In 1872 Rainilaiarirony applied to the Goremor of Manritius for an English drill-sergeant. This application was complied with, and $i$ non-commissioned officer was seut to Antananarivo, who trained a certain select number of young men of good family, who, when qunlified, drilled the soldiers. This non-commissioned officer remained for about two years, when be was replaced by another sergeant, who remained threo years. By this menus the natire army was supplied with a number of young Hora Officers capable of instructing their men, and foreign assistance was no longer needed.?

In 1867, shortly before the denth of Kasoherina, and subsequent to the payment of the French indemnity at T'amatave, the Hova Government thought that a demonstration of power was needed on the cast const. Radama's famous march half a century prerionsly forming a good precedent, as well as that by Ranavalona $I$ in 18.15. The Queen was hopelessly ill, and the pretest was made that a Royal progress to the coast wonld be for the benefit of her health, and the sainbrious hot springs of Ranomafana, near Andevoranto, were recommended by the doctors to the moribund Sovereign. In June the Qucen's camp eqnipment-and the escort were molilized: ronds were cut through the forestit, supplies furnished to the different stations on roule, and the order of march arranged. On the 10th the Quecn's palanquin left the palace, and tho Arms, with follorrers, numbered upwards of 60,000 men. One month was occupied in moring this enormous retinue to Anderoranto, where the force remained until the end of August, returning by the same route to the capital. The fatal casualties from sickness and oxposure alone, during this progress, amounted to 1,000 deaths, whilst the number of sick was in proportion. 'The Prince Ramonja and screral Officers of high rank succumbed to fever, and the Qucen herself did not survive her return to Antanamarivo many monihs.

'This march, whicle was made slowly and with ample preparation, gives an example of the unliealthiness of the line of country between Antananarivo and the east const.

1873. In 1873 sereral of the Salkalàra tribes in the south-riest had become so turbulent and daring, that it became necessars for the Hova Government to ndopt somo activo measures in order to prevent further difficulties. Under the circnmstances, the Government appeared to have bad no alternative but to enforce submission, and with this purpose, arrangements wero mado for sending out tro military expeditions under two of the chief Officers in the Gorernment. (One of them, Rainivoninahitriniarivo, was subsequently well known as the principal Ainbassador to Europe in 1882.). The two forces together numbered 5,000 men in addition to a large number of dekconc and personal followers. The Prime Minister addressed the expeditions before they started, and instructed the Officers to deal honourably with the Sàkalira, and do their best to settlo matters without

1 During the residence of the second drill-sergeant, tbe French Consul, eridently a little jealous of the preference eliom to English instruction, procurcd a joung French Oficer from Réunion; and offered his scrrices to Rainilaiarirong. This offer $\pi 2 s$ secepted in order that no olfenco might be giren to the French. 
bloodshed if possible. This advice was well received and faith fully acted $\mathrm{np}$ to by the commanders. From numerous reports the Europeans at the capital received of these expeditions they had erery reason to beliere that they were conducted in an honest, honourable, and straightformard monnei. The condnct of the Officers and men towards each other in the camp and on the line of march, their dealings with the people after they had arrived in the enemy's country, the manner in which thoy endearoured to settle the matters in dispute, and, in fact, the general management of the operationsall seem to have been characterized by a spirit of the highest discipline and self-restraint-a great contrast to former operations of the kind.

The object of the Government in sending these expeditions was not to obtain territor, military renown, or plunder, but simply to protect the weaker tribes which had been crttelly oppressed and robbed. The different Officers in charge appointed trustworthy orerseers to the camps to prevent all disorder and unfairuess, and especially took vare that nono of tho Officers shonld give extra burdens, consisting of their own baggage and provisions, to be carried by the bearers uncler their authority. Strict order's were enforeed that fo acts of violence or oppression on the people along the route, tlirough whose villages or markets the line of march might lead, would be permitted; guards wero stationed at these places to see the orders carricd ont, and all offenders were severely punished. Accommodation was provided for the sick, and Officers were known to gire up their filanzans (palanquins) to them, and even to assist the bearcrs. When treating with the enemy the chief Officers behared with dignity and firmness, and, conscious of their strength, nerer permitted oppression or plunder. Only one engagement wias fought, when the town of the rebel chief, Arahabo, was burnt as a punishment, and the expedition retarned without a hitch, haring accomplished the object for which they had been despatclied. The greatest liarmony prevailed throughout, and the manuer in which the business was carried out had a most lasting moral effect on the Sàkalàra tribes with whom they came in contact. No better proof conld be wished of the solidity of the army reform which Rainilaiarirony had initiated and carried out in spite of opposition and jealousy of the older chiefs in Imerina.

1876. Reorganization.-For many months during 1876, especially in Junc, July, and Augnst, great excitement prevailed throughout Imerina, for a military conscription was talked about and anxiously expected, bat tro preliminary matters required to be attended to before the proposed conscription could be carried ont. One was the reorganization of the existing army, involving the redistribution of Officers and brigades, and the discharge of old and worn-out veterans; and the other was the reorganization of the deka, ${ }^{1}$ which of late years had become a scandal of large proportions; for most of the higher Officers had appropriated to themselres a much larger number of followers and personal attendants than they had any right to. Both 
these measures of reform required delicate jet firm handling, and any reakness or hesitation might have led to a revolution, and cost the life of the Alinister and the ruin of the country.

At last on the 6th June, a grand Kabary was held at Imabamasina, when a message from the Queen was addressed to the Foloalindahy (literally = the ten thousund), that is the army. By this message all who had delia were required to make out lists of their names, and send them in to the Government within a fortnight. The teachers were also required to write down and send in lists of all their scholars. On the 13th July, after the numbers of deka passessed by each Officer had been sent in to the Gorernment, another Kabary was held, at which a Royal Message was read by the Prime MIinister. It condemned in very strong language the recent action of the Ofticers in withdrawing young men from the army and otbor departments, and attaching them to themselves as their own private followers. The address concluded by fixing the number of deka which each Officer was entitled to possess, and by declaring that, in future, any one exceeding that number would be treated as a transgressor of the law. The number of deka allowed is, therefore, now regulated by the honours of the Officer, which also indicate his rank, social position, and regulate his official standing. The highest number of delia which any Oflicer can now possess under the new regulations is 30 . and this is only admissible in Officers of the highest rank, viz., of 16 honours. Those of 15 honours are allowed 25 delia; 14 honours, 20; 13 honours, 15 ; 12 honours, 10 ; 11 honours, 5 ; 10 honours, 3 ; and 9 honours, only 1 ; the rest are not allowed anf.

By this law a large number of young men improperly kept away from military service were added to the army, and they were at once ordered to join as recruits, and were drilled with all possible despatch.

1878. In July, a great military reviow took placo at Imahamasina, the large lerel plain west of the capital. This review extended orer three days, when each company was reviewed separately, and went through the various exercises satisfactorily. The foreign words of command were ordered to be abolished, and have now been given in the Malagasy rernacular.

1879. On the 25th March, a great Kabary was assembled, and the popular anxiety in regard to the apprehended conscription was set at rest.

The following are the principal features of the new system of recruiting the Hora Arms :-

I. All classes are required to serve in the ranks, none being exempt except-(a) the sick and incapable, (b) pastors of churches duly appointed and recognized, (c) such as the Queen shall be pleased to free.

II. Instead of serrice for life, the time of service is fixed at fire sears, while those who are diligent and acquire the necessary qualifications before the expiration of that time will be treated with special farour. 
III. Tho enrolment of recruits will not be at irregular interrals, but take place annually.

IV. The soldiers will be no longer called ap to the capital to drill, but will bo drilled in their orn districts.

V. The soldiers will only be sent to distant garrisons for pericds of twelve months, and the posts will be regularly reliered annually.

A number of minor regulations are given, with a view to prevent oppression, bribery, and deception; whilst fines varying from 10 to 100 dollars are imposed on any found guilty of such misdemeanour.

Immediately after the publication of this Kabary, large numbers of young men were enrolled and at once placed under instruction; and on the 8th January, 1880, a review of these new recruits wis held at Imahamasina in the presence of the Queen, and was declared to be highly satisfactory.

1881. Admiral Gore Jones's Report.-Admiral Gore Jones proceeded to Antananariro in July, 1881, and in his report to the Admiralty he mentions that he considers tho Prime Minister one of the ablest men he has ever met. He (the Prime Minister) had given colesion. to the Hora nation, and drilled, armed, and formed an army of 40,000 men, and thus prepared the way for his people to gorern tho. wholo island de facto as well as de jure. His great difficulty was want of money. They had no revenne, except import duties; and in order to buy arms he had been obliged to get, occasionally, a squeese on property, bat this had to be done very judiciously.

The Hora troops were twice reviewed before Admiral Jones, who states that they are carefally drilled in the manual and firing exercises, but had only recently been armed with rifles. The words of command, originally giren in English, were then being altered into their own language. Great attention was being paid to the drilling of the recruits, and some 40,000 men were said to be available.

I had intended to gire some account of the late operations in Madagascar from 1883 to the present sear; but I find that the present. paper has already reached the limits that can be allotted to the subject, and, therefore, I must postpone the notice of the recent and present events to another occasion, more especially because there is some reason to hope that the present operations may be brought to a termination this season.

Howerer, at the expressed desire of our Chairman, I mnst not conclude without a brief reference to the recent operations of the French in the conntry which was onco named "Ia France Orientale." Of the rights or the wrongs of the mach-rexed Madagascar Question it is not for me to judge or express my sentiments here. For certain diplomatic reasons it was thought proper by the Republic to nse force against the Hova Government, and in accordance with the latest practice, hostilities were commenced, withont any formal declaration of war, by the destruction of the Hova posts at Morontsanga and Bemaneviky, on 8th May, 1883. The port of Mojangà was bombarded next by Admiral Pierro on the 16th May, a voL. XX1X. 
force lauded and the place occupied. The French next procecded to Tamatare, whence an ultimatum was sent to the capital, demanding certain conditions which were to be accepted by the 9th Jane. The terms were refused by the Hovas, whereupon the French opened firo on the fort of Tamatare from the six ships of the squadran. As Captain Charles Johnstone, R.N., is present, we may renture to hope that he will give the andience some of his personal experiences of that trying tine, when a number of distressed British subjects depended upon him for protection; aud when the presence of H.II.S. "Drsad" exerted a moral influence, of wonderful proportion con. sidering the inferior size of the sloopand her incapacitated armamert. The Hovas, who had nerer exhibited their flag, retired to their en. trenched position at Manjakandrianombana, some 6 miles in rear of Tamatare, where they have since maintained a clefiant attitude.

The French Admiral, as wo all know, after an unfortuuate illness, was summoned back to France only to die, being succecded by Admirals Galiber and Miot. The operations havo since consisted of the repeated shelling of all the small stations, which can hardly be called ports, wut linding places, whererer the Hovas have established Custom-houses. Tohemal was taken last jear at the close of the season, and I am informed that when the Hova garrison of Ambaniog was driren out of that place, a number of Antankara pursued tho retreating garrison and massacred a large portion who were unable to escape. Br the latest nerrs the Hovas are said to be inresting Mojaugà, but until authentic intelligenee is published, no opinion cra bo expressed on the tacties of the Hova soldiers, or on thoir behariour in the field. One thing appears certain, that the Hove military authorities hare steadfastiy set their face against the savage and barbarous practices which were chaneteristic of their warfare in former days. This adrance in cirilization has received lately most notable illustration by the kind treatment bestowed by the Fovas on: the French prisowers in their hands. ${ }^{1}$

I A despatch from Admiral Miot, dated Tamatare, Scptember 25th, gircs the following particulars:- The column adranced to within 500 metres of tho enemy's entrenchments, and notwithstanding the diffeudics cxperienced oning to. tho gro:ind to be trarersed, carried on a brisk artillery engagement with the Ûtoras for a space of tro houre. The Frencl were thus made a mare of the importance of the new lines of defeuce const ructed by the Horas and the strength of their nmaments, consisting of Remington riflez and sereral cannon of long rnge. Simultancously. with the surance of the troops the war vessels in the roads bombarded the leights of Farifate, while a landing party from the "Naindo" effected a dirersion on tho extreme left br feimning an attach on the rillage of Ampassicmandour. The Horn forces around Farifute are estimated at from 7,000 to $8,000 \mathrm{men}$. The French columm started at 5 s.M., and re-entered their cantonments at firo in the crening, liaring lost 2 hilled and 31 wounded. The Admiral arlds that on tho west coast of the island, on the uight of tho 29th August, the Horas set fire to the rillage of Zougvo, situsted 2.4 miles from the military post of Amboudimadirou. Learing a suficicat garrison to defend it in case of attack, Captain Penneguin, the Commandant, went in search of the enealy with a small column of 120 men, of whom 70 were Sakalaras. He came up with tho Iloras on the following dias in the ralley of Sembirano, and completely routed them with hears loss. The French bad 1 Oficer killed and 2 Oficers and 9 men rounded. The general health of the troops on shore aud on the ressel in the larbour is satisfactory. 
Captrin Crances Jorrstose, R.N.: Mr. Chairman, ladies, and gentlemen, I have some diffdence in beginning a discussion of this sort, because my acquaintance with Madagasear is rers small comparcd with that of many who are here present, and therefore in any remarks which I may mako about that country I shall be prepared to bo corrected. Tho natire races of Mndagascar are not, as might be imagined, all one people. They are composed of different tribes. Some of them are curly. headed races and others stmight-haired. The straight-haired are Horas, and I beliere $I \mathrm{am}$ correct in sajing that they are the only straight-haired race in the island. The others apparently are connected with the native races on the mainland. The origin of the Horas is rery obscure, in fact, they hare no mitten histors. Their Innguage mas only a spoken one up to the time when tho Christian missionaries from England began to edvicate the races, and reduced the language to writing. Up to that time the race was a rery sarage one; in fact, they hare no records at all. From rarious inrestigations it is concluded that they hare in some way found their way across from the islands of the Eastern Archipelago to Madagascar, and lare gradually worked their was up to the centro of the island; and established themselres in the prorince of Imérina. We have by a sort of courtesy of late called the Queen of Madagascar by that title, but I am bound to say I think her claim to it is not derired by actual right. Radama $I$, as our lecturer lias told us, was the first to extend the rule of his race from the prorince of Imérina domn tomards the coastline; but there is no question about it, the IIora ruce is not absolute all orer the island, nor orer a rerge farge part of it; a portion of it does not at all submit to the Hora rule, and especinlly the part marked on the map Tullear, where the Horas are utterly unablo to restrain the barbarous people. Therefore, there is something to bo snid for the French in the action which they hare taken with regard to Madagasear. It would be diftienlt for anjone to approre entirely of the way in which the French hare gono to work, but $I$ think if ang European Power had arrired on the const of Madagascar, and found many parts of the island unoccupied and not under Ilora rule, they. would hare cstablished themselres there, and considered they had a right to do so. The fault that must be found with the French by all cirilized people is that they. hare not gove there with a distinct riew of improving the people, and, in fact, it is rery diffeult to say that they hare gone there with any distinct riew at all. To my mind it may fairly be called a flibustering expectition. In undertaking the conquest of a country I imagine you incur certain duties and responsibilities, and the French do not seem to me to liare gone entertaining that riew at all, or with the sense of those responsibilities. The result is that they have an insufficient foree there, a force which does not appear able to orereome any difficulty other than that of just kecping small places on tho coast-line. But of that $I$ - hope the lecturer will tell us something further. It would be rery interesting if the could tell us what possibility there is of a Europcan force getting lip from Tamatarọ to the capital Antanánariro, and taking posscssion of it; and, moreorer, our Chairman might give us complete information on that eubject, as he made the long and diffeult journes up to the capital itself. Therefore, it would be rery interesting to know exactly what prospect there is of the. French, with the power they bare, establiahing themselves and conquering the island altogether. I beliere one of tho principal reasons why the French hare got there is that they were puslied on by the Colonists of Bourbon. MIadagasear was a sort of Eldorado, a promised land to them. They were urged on by different people to go to the conquest of Madagascar, but now, not laring been able to get on as rapidly as they hoped to do, the thing has rather fallen through. It is supposed that there are considerable riches in Madagascar in the shape of mineral wealth, but the present Prime Minister, who is rirtually ruler of the country, has with, I think, perhaps much urisdom, absolutely refused to allow any scarch to be made in the soil for precious metals? He understands thoroughly well that if gold or silrer were found, there would be an influx of certainly not. the best people from other countries, and that the country would be overwhelmed with forcigners of a rery cloubtful sort. Therefore, he thinks, in the present state of cirilization of the country, it is rery much better to discourage it, and I am inclined to think he is perfectly right. If the French had gone there with a single object I do not know that there could be so rery much to be said against their position, but when ther 
went there the other day they suddenly came down upon the Iforas, who undoubtedly looked upon themselres as possessors of the whole islnnd, and they demanded ail the northern portion of the island down to the 16th degreo of latitude, which was certainly a rery strong demand. Since that time they hare been receding from their former demand, and it is likely now they would bo satisfied with but little. It is rers singular to obserro how, in spite of very serious menaces from a great and orerwheIming nation like the French, the Horas haro still been enabled to hold out. One of the things greatly in their farour is that there are no roads in the island. There is not eren a road that a pack-horse can go along. In going from Tamatare to Antananóriro I am told you could not so much as take a loaded pack. horse under the trees. Eversthing lias to be carried up on the backs of men. Ererybody who trarcls is carried in a palanquin, and all weights are carried up on men's backs. This is a rery serious difficulty for an inrading army, but I beliere it is a matter that our lecturer has gone into, and he can explain how it might be orercome. The French are not disposed to go up to the capital from Tamatare. They suppose the best line of adranee would be from Bembatoka Bay on the north. west cosit by the river to Ikopa. The boats of II.AC.S. "Ruby," some years ago, rent 100 miles up from the sea, and it was said the remainder of the way up to Antananáriro would be comparatirely casy. The Horas are rery far from being a warlike people, and if it comes actually to fighting I am not at all sure how they would stand. Up to the present time the dificulties of the country haro been so great that the Erench hare been able to do very little. As I said the Iloras are not warlike, in fact, their plan of fighting is this, they push all the lowest soldiers to the front, and the Commander-in-Chief is alwass a mile or two in the rear, so it may well be supposed that an army would not fight particularly well in that state. If they hare European leaders they will alter that, but the first thing that was done in the case of a recent attack on one of the seaports was that the Commanderin.Chicf cleared out and left his troops to do the fighting. The population of Madagascar is a decreasing one, as unhappily the curse of strong drink is amongst them. Rum is manufactured in the Mauritius and Bourbon, and brought orer. It is imported by unprincipled traders, and sold to the natires, who drink it like rater in many coses. They are utterly ruined; and not only that, but they lare a way of making spirits themselres of a most poisonous description, which is undermining the physique of all the northern races. I was told by the French that the Sàbaldras, the people that tho French themselres propose to put forward in opposition to the Horas, were quite a dying-out race in consequence of their rices. So that it is rery questionable what the future of Madagascar with regard to the races will be, and unless they improre, and cirilization has a much better effect upon them than it has had up to the present time, I am afraid the natire races of Mrdagascar will gradually die out. The soil is particularly rich, especially on the sea-coast and along the castern shore. It is a rery unhappy thing for some of our fellow-countrymen that they hare cmbarked large sums of money in commercial enterprises, cspecially in the neighbourhood of Tamatare. Large sugar plantations hare been ect on foot, and at the time of the French attack, the people who suffered mostly were our onn people, natires of the Mauritius as a general rule. Large sums of money were inrested in theso sugar plantations, and at the outbreak of hostilities it was known that if natire labour conld not be obtained to gather in the sugar-cane, the crop for that year would be lost. They then said if it rere not gathered in at the end of the second year the plants would be entirely destroyed, and this, I beliere, in almost erery case has taken place. Not only hare the crops been destroyed, but the plants also, and the whole money spent on these things with the exception of perhaps a little material sared in the workshops, crergthing has been absolutely lost. I $\mathrm{Ear}$ a gentleman in the Mauritius who had been a rich landowner not ver, far from Tamatare, and I was told he scarcely knew where to look for a meal. This is the unfortunate result of hostilities between Madagazcar and a Power like the French, and I think it is a matter which deserres the consideration of civilized people whether war ought to bring suel misfortunes not upon people's encmies but upon their friends. $A s$ far is our interests go with Madagascar they are principally thoso connected with the Mauritius. Of course that affects the United Fingdom morc or less, but there are rery large British interests 
connected with the Mnuritiug; and should the French tabe pessession of Madagascar, as it is supposed they wish to do, $I$ am alraid our interests would die out com. pletely, and this would be a rery scrious loss to many of our prople.

Mr. doranasr hisadox: I Jope we do not mean to let the interest in Mradagascar die ont. It is a large and important island. The land abounds in mineral wealth, timber, india-rubber, cattle, and rice, and it mill produce almost anything. We can get away up into altitudes of about 5,000 or 7,000 feet; we can grow and cultirate many things which can bo grown and cultirited in the southern parts of England; then we get a rariety of productions on the coast, the differences in the climate being rery great. All that is rers much in its farour as a country for production. Its woods are almost invaluable, comprising ebony, sandal wood, satin wood, lignum rita, and roods the liko of which hare nerer been eeen here-of beautiful grain. I hare woods at lome similar to the finest borrood, and also one of tho conmonest woods in the country rery similar to Spanish mahogany. It was only a few weeks since that a large timber merchant asked me, "Is there in Yadagascar anr substitute for. Spanish maliogany, for we are getting very short of that; in fact, after a time, we slall not be able to get it at all." "IVell," I said, "in Madagascar the nood that people use for making their floors and doors and tho general wood-mork in their bouses is equally close grained and good with Spanish mahogans." Then as to mineral wealth, we do not want to say too much about that, but I think we are all pretty well agreed that Captain Johnstone is right in sajing the Gorernment is justified in prohibiting the influx of a rers doubtful class of foreigners, but I think when the right time comes it will be a splendid thing for the Gorernment to allow mines to be worked under supervision, or under the rosalty system. I think it would add rery materially to their ability to protect themselres. It is the money they want; they hare the men, but it is the movey they want wherewith to buy arms, and they are perfectly justified in defending themselres against aggression. dnd thes are men of brains and goud natural parts. Those of us who hare lired long in the island know rery well that the Malagasy are capable of doing anththing that it is pussible for a European to learn. 'I could show jou come samples of beautiful work in water-colours, also in gold and in iron rork. They are not barbarous, as some people imagine. They are an intelligent race. capable of adrancement, and no man who lires amongst them and has any feeling of brotherhood at all can experienco their hospitality and generosity without feeling an affection for them. I therefore speak with feeling when $I$ say that $I$ hopo Englishmen will not lose interest in Madagascor. We want to be cautious and careful in order to retain our interests there. We do not want the French to tako our place in commerce or in instructing the pcople in a great deal in which we do not beliere. The outcome of the instruction of the Horas has been their superior position, and what Captain Jolunstone has said about the decimntion of the Sabalara population through the exterminating effects of intoricating liquors does not apply to the people in the interior, where there is a prohibitory liar, and the result is that the people are increasing and not decreasing. It therefore behores us not to giro up our interest in these Malagasy, but to do all we possibly can to bring about an amicable and peaceful settlenent of this long-rexed question.

Mr. Corsiss : There is just one point that occurs to me arising from the discussion, that is, the question of the position which Europeans might oceupy in the island of Madagascar. I do not think the Malagasy will erer be able to derelop their own resources unassisted; I hare thought so now for some years. I think they need European guidanco; they need the stimulus of European thought and enterprise; but under guidance, with help, thes are certainly capable of rers remarkable derelopment. Before this diffeulty with the French occurred, I think many of us who were living in Madagasear thought the policy of the Horas was decidedly false, that they were eeeking to repress the energy of Europeans, that they were putting difficulties in the was of the introduction of European capital, and so on; but the French harc completely turned one's thoughts from this into other directions through the foolish and I may eay the crucl way in which thes hare gone to work. They had practically* no grievance that ot ler European nations had not. Their difficulties wero the diff. culties of all, and could there hare been anjthing like a joint protest or a joint action, I think a certain amount of pressure would hare been very useful to the Malagasy. 
The resonrces of the country were to a large extent shut up, whercas they ought to hare been dereloped, and I doubt whether, excepting as tho result of pressure, there would hare been any great derelopment. But the French hare gone to work in such an altogether extraragant xas-such an unjust was-trumping up charges which are positirely babyisl when you come to look into them, that it is almost impossible to look at the matter in the fair all-round way in which one rould naturally hare been disposed to do, and whilst they are acting as at present.our sjmpathics are naturally with the weaker party: But apart from that, I think the influence of Europeans ought to inerease rather than decreaso in Madagascar, and if any arrangement could be mado by which this present difliculty could be orercome, and a satisfactory treaty made with the French -our own is made-and if freedom could be giren to people with capital to introduce, I think the future of Madagascar would be one in which we should all rcjoice. I am personally rery much indebted to Captain Oliver for the interest and sympathy he has shorr with the island, and especially for the excellent book which he has recently written on the true story of the rupture.

The Rer. G. SnAw: We hare heard a great deal this afternoon of the Sakalara; we hare heard that they are unconquered, that they are a sarage race, that they are dirided into a great number of tribes, and that those tribes are continually fighting one with another. Now I think this requires a little explanation. These so-called tribes, if $I$ understand it aright, of the Sakaldra who are so continnally at.war are not, as we should account them, tribes in the true sense of the term. . Each is a small community, generally speaking, consisting of one famils. That is to say, the whole inhabitants of a sraall hamlet or rillage are united by somo kind of family tie; they are ruled orer by a so-called king, and the rarious jealousies which arise may be looked upon as family jealousies-jealousies between the head of one family and the liead of another, and these hare caused the rarious raids which I think should hardly be called wars. It has been represented that in these wars rery fer are killed, that perbaps one is rounded, or that ono mas be killed, and that the nerrs of this spreads from one village to another; and that then the war is orer. Now I think this creates a slightly false impression. It is quite true that there hare been wars among the Sakalaras, but I do not think that such raids from village to village ought to be dignified by the name of wnrs, and by being so ealled they certainly gire a mons impression to those who live outside Madagascar, and do not know exactly how the matter stands. Another point in regard to the wars which has not been brought with sufficient prominence before us-it may be in the paper, but unfortunately $I$ have not seen the paper-is that we have heard that the Hovas in former wars, that is, under Radíma I and under Ranaralona I, were excessirely cruel and sarage. There is not the least doubt that this is true. When the Iforas went with the endearour to orercome some of the surrounding tribes, their conduct of the war was doubtless rery cruel; they massuered all those who wero unfit to be slaves, that is to say, those who were too old or too infirm to be used in after-time as slares in another part of the country; but since the time of Ranaralona I there have also been wars which correspond in rery great measure to the mars of Radáma $I$ and Ranaralona I so fur as the object is concerned, that is to say, the Horas hare been sent from the interior of the island to some of these outlying tribes in order to subdue a rebellion or to make them thoroughly subject to the Horas. These wars hare been marked with anything but sererity; indeed, they hare been characterized by a greater amount of leniency and mercy than is rery often shown in so-called cirilized warfare. A Hora army was sent on one occasion to the south-west in onder to orercome a certain rebellion, and it is well known that the lato Queen, before despatching the army, gave explicit instructions that unless it was absolutely necessary, no one was to be killed; it was to be a war in whicb, if possible, bloodshed was to be entirels aroided; and so stringent were the Queen's orders to her Officers that this was actually the result. - I beliere I am correct in saying that although some 10,000 or 15,000 soldicrs and camp followers were engaged in that war, not a single person was killed: and this has marked all subsequent wars in Madagascar. There has been, I beliere, no war in Madagascar since the time that Cluristianity actually took possession of the minds and hearts of the rulers, which has been marked by anything that can be called cruelty, but rather on the other hand by the 
ntmost mercr. This, I think, it is important should bo made rers clear, and I hare therefore laid some stress upon it.

Tho Cratruray : Beforo Captain Oliver sumb up $I$ should like to call attention to a few dates. Madngascar was discorered by the Portuguese under Ferdinand Suarez in 1506, and to tham belong all the honours of first discorery. When we had some discussion with regard to Delagon Bay, tho matter mas jeferred to the President of the French Republic, and he decided against England, because the Portuguese were the first discorerers, and that is a rery important point to be remembered in dealing with the present position of the French in Mradagascar. In 1509 King Emanuel of Portugal sent Lopez de Sequera, and the follorring rear Juan Serrano, to cxamine the country and organize an establishment for trade. Missionaries established themselres at that period, the Christian religion was introduced, and sereral hatires, including the son of a great chicf, were sent to Goa for education. Howerer, they disappeared, like all the carly settlers, and in 1595 the Dutch formed trading settlements, the remains of which aro ecen to this day. They also disappeared, and in 1613 the French, in the dajs of Richelicu, formed La Société de l'Orient, and to colonize MIadagascar was their great object. They camethere, and established themselres due south at Fort Dauphin, haring previously. prospected the country a little. Flacourt was the first Goremor, and fire or six years after his return to France at that period he wrote a "History of Madagascar," and in that history he states that there was an English Colony of 400 in the Bay of St. Iugustine in 16.14. For a Colony is not a mushroom; it does not spring up in a night; and this shows that the English had a Possession or Colony in Madagascar a long time before the French. Some of the French attempted to desert from Fort Dauphin, and found their waj to St. Augustine, to take shipping: for Europo; but on arriring at the Colony it was found that there were 300 or 400 grares, the Colony itsclf haring rirtually disappeared. It also showed another thing; that at that period Madagascar was a general place of call for shipping. There secmed to be no dificulty to get to or fro from it, and therefore the only conclusion we can come to is that the English were thero as colonists before the French. The right of discorery belongs to the Portuguese, and the introduction of cirilization first to the Dutch, then the English, and lastly the French. In his lecture Captain Olirer speaks of thirty or forty jears ago, but the whole world has altered within the last ten or twenty years, and the Malagass hare altercd with it, and now I consider that the IIora population, gorerned by the Prime Ifiaister, are as moral a people in erery respect as can be met with in Europe. They aro kindly: hearted, hospitable, and well-mannered. I have met men there as perfect gentlemen as jou could meet in any room in Iondon. We hare lrad their Ambassadors: orer here, and these men were gracious in their manner, plasing in their conversation, and in fact thorough gentlemen in erery respect. It must be borne in mind, too, that this is due to themselres as well as to the missionaries. They had receired their education from the missionaries, and it is being handed on to the third generation. There is no doubt but that thes are a bighly intelligent people. If jou unt into the rooms of Mrr. Rassange, who is well Enown to many here, you would find there all the standard works of English authors, and he has read them all. How, then, can the people to whom ho belongs be called sarages? The journey that I made up to the capital occupied six meeks, and if you were to ask me whether it was possible for an army to go up there I should say certainly not. We all trarelled in filansanos, which are like a child's perambulator stuck on a couple of poles, the corers of which were painted to keep off the eternal wet. It was with the greatest difficulty that we manceurred these filansanos through the fissures of the rocks and across many of the strcams, and when trarersing the forests we were two dajs without secing the light of hearen. If there were a decent enemy to oppose an invading foree I beliere that not one person could get up to the capital. The inhabitants of the rillnges pay no taxes, that is, those living on the high road up to Antananáriro; they are, therefore, obliged to gire Government trarellers free lodgings and cntertainment, and thus at cach rillage the number of rooms wo required were cleared of the people, animals, poultry, \&c.-for they all lived together-and then some new pieces of matting were sprend orer the old filth and dirt; and hence new matting is the name applied to the seriptural trans:- 
lation of hypocrisy. Their languago is expressive, and sentences are used for words : for instance, the name of a turkey-cock is " the bird not to be afraid of," because they soon found that though it made a good deal of bluster there was nothing in him to cause fear. Our marmeeds (domestic slares) were soon drilled in placing properly ererything required, so that our European serrants had but little to do besides making the beds and arranging the meals. When we arrired at our halting rillage we generally found an ox stretched full length on its side, with its four legs tied up, and a number of turkeys, geese, fowls, sugar-canes, and parcels of rice around it. Then a deputation waited upon us, headed by the chief man of the rillage, who made us an address of relcome, expressing their pleasure at seeing us, and enumerating tho offerings they had brought. We always paid them for their presents pretty nearly the full ralue, so that they did not suffer angthing. 'Tlie houses mere made of rushes, and thatched with palm leares. That was the case until we got on to Hora ground; there we found adobe buildings and houses made of rough sun-dried bricks, and placed on far more farourable sites than among tho coast tribes. When we were about 50 miles from the capital we met a deputation of firo gentlemen of the Queen's houseliold, which mas considered a great honour. Tro dass afterwards, a deputation of higher officials met us, and we had a repe. tition of the first reception. On the sirteenth day we balted half-an-hour from the capital, to let us rest and put on our uniforms for the grand entry tho next daj. Here we were risited by nearly all the forcigners in Antananáriro. During the last three days of our jourey we were in the. Hora province of Imérina, and there was a marked improrement in the condition of the land and houses; the rush hut had disappeared, and cottages were built with solid adobe walls, or of rough bricks, and as we approached the capital the houses got better and better, and the ono I was lodged in was as well got up as an English suburban rilla. The next day, Friday, Jul 1, we made our entry in swords and epaulettes. The band, troops, ofticials, and all the Europeans joined in the cortége. We were carried in the Rojal filansanos, and the chicf military officials were on horseback. Although the distance was little orer a mile it took us two hours to reach the capital. Shortly after starting we stopped and salnted the two Queens, the whole of the troops presenting arms, and the band plajing the national airs. The peculiarity of the whole country we had trarelled orer was its unerenness; except the Ankay plain it was all up and down. Tho scenery was raried, and in some places beautiful, it nerer approaches the grand. The upland soil generally produced a long coarse grass, which scemed well adapted for pasture purposes; the patches which were cultirated did well, and coffec, sugar, manioc, rice, and other vegetables seemed to flourish; but the land as a whole scemed uninlabited, and eren the cattle were ferr. From its formation there can bo little doubt that there must be much mineral wealth in the country. The forest we passed through had no fine timber, but a small and twisted undergrowth and tall lanky trees, suffering from excessire moisture and want of sun. When we mero rcceired by the Queen it was really a most imposing sight. 200 or 300 people were there; the Queen was on the throne, with a diadem on her head, silks and satins and grand dresses were to be seen in all directions, and all the pretty joung ladies sat on the steps of the throne. Altogether the secne was one which bespoke extreme cirilization, and ereryone was excecdingly courteous in manner. Now, the point ire want the lecturer to speak to is the getting of troops up to Antananáriro, and it is with regard to that question that the Prime Minister is such an extraordinarily clerer man. He hrows rery well the difficulty of the roads, and the almost impossibility of passing them, but he does not want foreign troops to reach the capital, and so he prefers the less eril of bad roads to the greater cril of the French coming up. If thes altered their route, as they talked about doing, to the northwest coast, I think it would be wise, becauso the Prime Minister tried to send his troops round in that direction when the row took place and the flags were cut down, which brouglit on the first part of this disturbance. The misunderstanding aroso chiefly from misconception, for the French imagined from the expedition which went up with me that we were taking some rery decided steps to do what they were wishing to do-to annex Madagascar. It hurried them, und then they eent out their new Consul, who was well known to be a freater, and after that all chance of peace was at an end. 
Captain OLIrer: I hopn it is quite understood that in my paper I did not attempt to gire any description of the country, or. of its topographical or commerciul adrantages and disadrantages. I confued my paper entirely to examples of military operations. At the same time, as there has been a great deal of interest exhibited with regard to the topograplical fentures of the Hora country, its distance from the const, and the character of the harbours, I shall be happy to make a few remarks upon those points. Our Chairman said that there mas a question as to the route for troops up to Antananárico. Ifo has trarersed that country himself, I beliere in a chair or sedan, but I mysclf walked up nearly the whole distance, so that $I$ pretty well know what the road was like in $1 S 32$. It is certainly a rery diffcull route for troops, and tho Malagasy up to the present time hare been wise in not making a road as thos hare been advised to do by European Porers, especially by those most disinterested people, the French. The present Prime Ilinister is quito alire to the adrantages which will accrue to making a road, and there is no doubt that as soon as affairs are settled, as I hope they will be this session, a rery short road will be made up from the coast to the capital, which will then allow of the country being properls developed.' The great defence that the Hora country has had from Europeans has been their two Generals, 2 forcst and fever, and they hare atood them in rery good stead, as they harc other cirilized countries. Of course, civilization must mako its way up, and then roads will be made, and I hare no doubt that wo shall be able shortly to take rcturn tickets to Antananíriro by trammay if not by Failway. By that means the ferer will be escaped, becauso it is confined to a rery small belt on the coast, and eren this may also be conquered bJ quinine. There are sereral other points raised by spcakers this afternoon, amongst which I think the most importanc is that in which it has been said that the Jalagasy cannot clepend upon them. selres, that they need European guidance. There is no doubt that any strong European nation, the French especially, if they chose, could morch up and take the whole place, but whether it would pay them to do so is quite another question. Wre oursclves know what our troops hare dono in a similar country, for it is rery much like Afghanistan. Anj one of our flying columns could march orer the wholo place, here, there, and ererywhere, and think nothing of it. 'The French hare had not quite similar, but perhaps somewhat parallel, experiences in Annam and Tonquin, and if they like to expend the lives and the money thes can do the same; but I da not think it will erer pay them to do so unless they mean solid, permanent occupa. tion, colonization, and administration of the island, and that they are not likely to do, for Mr. Brisson's Gorernment scems perfectly opposed to anything of the hind. I hare no doubt that at the next Freneh elections the one great cry will be not to expond more French lires and money in Madagascar, and to nithdraw from the island. In fact, it is almost settled that they will do so. Then comes the question whether the English, French, and other uations may not see it to their adrantage to hold possession, bj the leare of and in conjunction with the Horas, of the ports in the north of MIadagasear which cannot otherwise be dereloped. Is long as they are under the Hora Gorernment they cannot be dereloped. Ther might be made frec ports, for they are tho most splendid harbours in the rorld. 'liney are half way to India. We saw how the suez Canal was blocked for sereral days rery secently by the sinking of a dredger, and by the sinking of a fer lighters, designedly or undesignedly, the whole Suez Canal transit could be stoppei for a long period. Then English trade would go round the Cape, and then the possession of good harbours on that side of it would be erersthing. Tho future welfare of the Malagasy will depend upon their being acknowledged in Europe, in the same manner as the new Congo State is acknowledged as a free State by the Great Europenn Powers. The free ports of Madagascar will then do a great deal to extend trado and promote the safety of English, American, and all other com.

1 Antananárivo is only about 70 miles as the crow flies direct to Andororanto, 60 miles south of Tamatare. The natiro runners, stationed in rélays, manage to accomplish the journey to Tamatare in four days.

"Generals "Hizo" and "Tazo."

3 The result of the elections in France has since justified this remark.-S. P. O. 
mercial trade in the Indian Ocean. The harbour at Diego Suarcz Bay is infinitely superior to anything you can find in Mauritius. Diego Suarez Bay is about half. ray between the Cape and Cejlon, and I think we may look for the opening of sereral free ports there. You may call them Hora, but they must be under tho protection of some European Power, and there is no doubt what that European Power will be, because it is the onls Europcan Power that bas dominion of the sea in all the scas. With regard to the remarks of Mr. Shaw, who has experienced the contrasting mercies of the combatants on both sides in Madagascar, I hare tried to point out in my paper that which I hope he will read in detail afterwards-the difference between the Ilora and Malagasy warfare of olden days, and the marfare of the present time. It appears certain that lately the Hora military authorities have steadfastly set their faces against the sarage, barbarous prictices which were cliaracteristic of their warfare in former days. Now, the Horas concluct their rars-such wars as they hare to carry out-with erery knowledge of the canons of warfare as far as regards its cirilization and amelioration. They acknowiedge the ambulance and the Red Cross, and behare themselves like cirilized nations. I do not know that they hare always receired the same consideration themselres, but there is no doubt that the change which has been effected is due to some of the gentlemen here this afternoon-JIr. Cousins, Mr. Kingdon, MIr. Shaw, and othersand to the example of some Englishmen who hare lired a good life among the Foras, and hare induced them to gire up their sarage practices and conform them. selres to modern ideas of warfare. War has been fored upon them by an iurasion of their country, but it is not for me to pronounce on the rights or the wrongs of the quarrel, though I may say this, that the Iloras will yield to none in their merciful and humane procedure of warfare. Perhaps I may quote a few figures of Admiral "Galiber, who was examined on a Committee last year by tho French Gorernment. IIe said that out of a force which the French liad of 1,100 men of all serrices there were 30,458 days in hospital, that is, for a period of sir months 690 men were inralided to Réunion. The cases of malarious ferer amounted to 27 per cent., 1 and, inclusire of those cases at the hospitals in Réunion, the total was 40 per cent. On the 12th February, 185.1, there were 268 cases of ferer in the force, which slions that with their present numbers the French hare no chance of adrancing into the interior. Of comrs, if they liked to send a large force there is no doubt that they could walk orer the IIoras as they liked, but to heep a small foree at Tamatare and 3rojangi of $2,000 \mathrm{men}$ with 12,000 surrounding them will be uscless. Unless the French really mean to make a conquest and adrance a large portion of men, it will be impossible for them to subdue the Horas. Admiral Wilson wrote to me the other daj, and he said ho did not think that a foree under 14,000 men could adrance on the capital. Unless the French aro absolutely determined to make up their mind to expend the amount of mones required for an expedition of that size they had best retire. They may. loold Mojangi and Tamatare and small ports on the coust for a certain time, but the Malagasy can afford to wait. I thint that all cirilized nations mill join in hoping that the Horas may be allowed to derelop themsclres into a nation. They hare shown themselres capable of progress, though up to a few jears ago they were a very cruel race. They are the only people who can make Iradagascar a real country. If we tried to annex the island we should hare to depend upon them to rule the interior, and wo should also hare to depend upon the natires to do our work as coolies. Unless the French make it a real French Colong, which seems to me impossible, they cannot hope to succed. We can only trust that in future they rill leare the Horas alone.

The Cnarryax: I am sure, ladies and gentlemen, you will all join in giring a rote of thanks to Captain Olirer who has so kindly giren the lecture, and imparted so much information to us to-day.

2 The French possess a delightful conralescent eștablishmont at Salazis, scme 3,000 feet abore the sea in the island of Réunion. 